\title{
Trumping the Environment? An Empirical Perspective on Investment Treaty Arbitration
}

\author{
Daniel Behn ${ }^{1}$ and Malcolm Langford ${ }^{2}$
}

28 August 2016

\begin{abstract}
Investment treaty disputes involving an environmental component continue to be at the forefront of many of the ongoing legitimacy debates in investment treaty arbitration. Critics of the investment treaty regime hold that arbitrations challenging domestic environment-related regulations have favored the property rights of foreign investors over the need of the state to (environmentally) regulate in the public interest. While there is some anecdotal evidence that this is the case, we ask in this article whether the universe of investment treaty arbitrations to date - in the aggregate - is as problematic for domestic environmental protection as has been perceived? With mixed-method techniques and the use of a set of factors that are commonly present in environment-related cases, we create a more nuanced picture of what types of environment-related cases are likely to be problematic for domestic regulation and which are not. Overall, we find that critiques of the system require empirical nuance. There are particular types of environment-related cases that are more likely to pit foreign investor rights against domestic environmental regulation; and that in the aggregate, the most problematic cases actually find in favor of states.
\end{abstract}

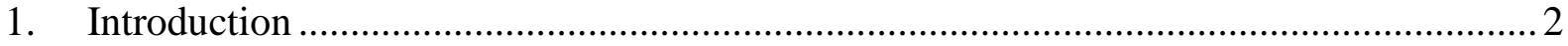

2. A Typology of Environment-Related Cases ................................................................ 3

3. Evaluating Challenges to Environment-Related Measures ........................................... 6

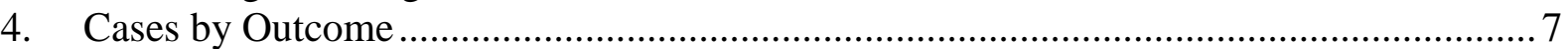

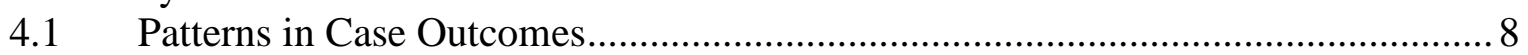

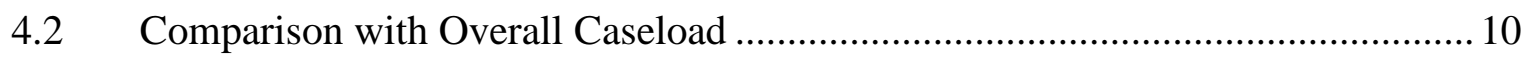

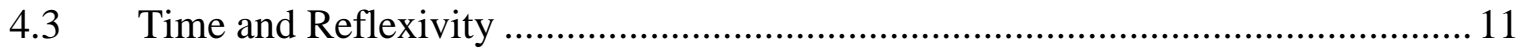

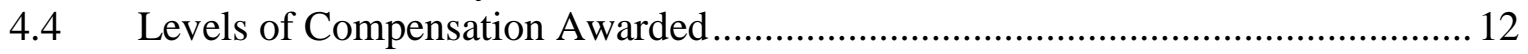

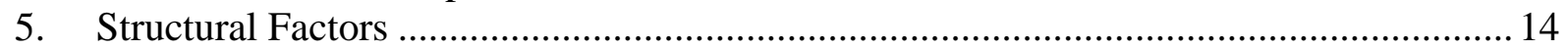

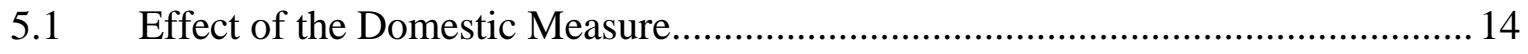

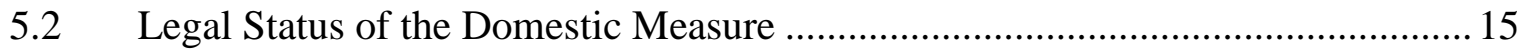

5.3 Level of Domestic Government Involved.............................................................. 16

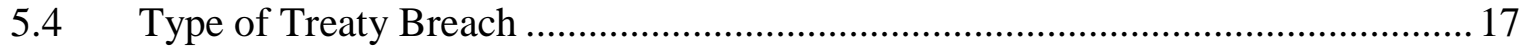

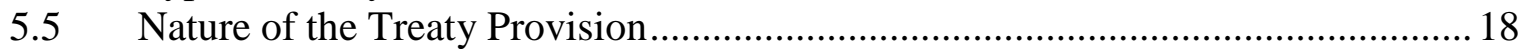

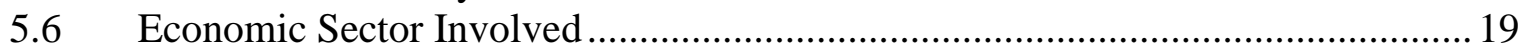

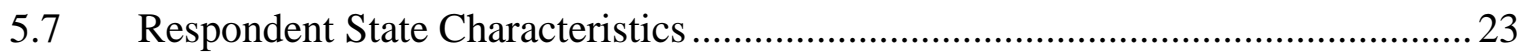

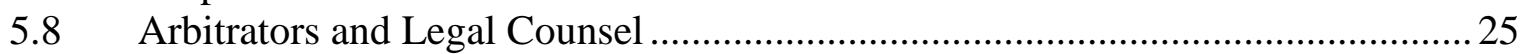

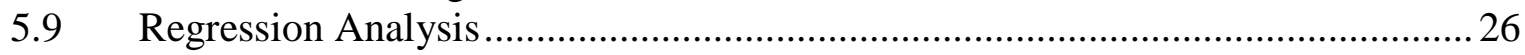

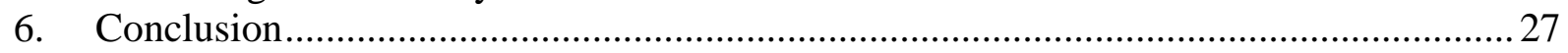

Annex I: List of Environment-Related Investment Treaty Arbitrations .............................. 27

\footnotetext{
1 Postdoctoral Researcher, PluriCourts Centre of Excellence, Faculty of Law, University of Oslo. Email: d.f.behn@jus.uio.no.

2 Associate Professor, Faculty of Law, University of Oslo and Co-Director, Centre on Law and Social Transformation, University of Bergen and CMI. Email: malcolm.langford@jus.uio.no.
} 


\section{Introduction}

The treatment of environment-related questions in international investment treaty law has been at the forefront of the legitimacy debates concerning the use of investment treaty arbitration for almost two decades now. The tension between domestic environmental protection and foreign investor rights in treaty-based arbitrations has been one of the primary drivers in what is now commonly referred to as the 'legitimacy crisis' in investment treaty arbitration. Scholars and civil society actors have continually raised concerns that the domestic policy space for environmental protection regulation has been 'expropriated' by the investment treaty regime, either through the threat or instigation of arbitration ('regulatory chill') or through actual arbitral awards requiring states to pay foreign investors sizable amounts of compensation for what respondent states consider to be legitimate policy choices. ${ }^{3}$

These charges against the legitimacy of investment treaty arbitration in disputes involving an environmental component largely echoes broader and oft-cited critiques against the entire investment treaty regime, which include inter alia that investment treaty arbitration is proinvestor, pro-investment, anti-developing state, or a combination of all three. Investment treaty claims that challenge domestic environment-related measures, while relatively few in relation to the overall caseload of treaty-based investment disputes (about 10\% according to our definition), have tended to exacerbate the perception that this type of arbitration is not only bad for states but is even worse for the environment.

Whether these environment-inflected legitimacy claims can be sustained forms the basis for the research question taken up in this article. To what extent - as empirical fact - is investment treaty arbitration stacked against the environment? When and how often do the rights of claimant-investors trump domestically implemented environment-related measures in the context of investment treaty arbitration? Is there a shift in outcomes in these types of cases over time that would evidence a greening of investment treaty arbitration? These questions are not new. However, the current scholarship is primarily legalistic in its methods (analysis of doctrines and treaty texts) and qualitative (with case studies on particular cases or potential incidents of regulatory chill). ${ }^{4}$

In this article, our approach is largely quantitative. We focus on aggregate measures of case outcomes and various structural, legal, and procedural factors that shape cases that come from our database of more than 780 registered investment treaty arbitrations. ${ }^{5}$ This quantitative analysis is mostly medium-N (drilling down on different features in cases involving an environmental component) and partly large- $\mathrm{N}$ (comparing cases involving an environmental component with all other investment treaty arbitrations and charting whether there are changes in outcomes across time). While this approach is intended to complement existing doctrinal and qualitative perspectives, it also provides an alternative lens by which to test various claims in the literature.

\footnotetext{
${ }^{3}$ Kyla Tienhaara, The Expropriation of Environmental Governance: Protecting Foreign Investors at the Expense of Public Policy (CUP 2009).

4 See eg Marie-Claire Cordonier-Segger, Markus Gehring, and Andrew Newcombe (eds), Sustainable Development in World Investment Law (Kluwer 2010); Jorge Viñuales, Foreign Investment and the Environment in International Law (CUP 2012); Pierre-Marie Dupuy and Jorge Viñuales (eds), Harnessing Foreign Investment to Promote Environmental Protection: Incentives and Safeguards (CUP 2013); Kate Miles, The Origins of International Investment Law: Empire, Environment and the Safeguard of Capital (CUP 2013); Kate Miles (ed), Research Handbook on Environment and Investment Law (Edward Elgar 2016).

${ }^{5}$ PluriCourts Investment Treaty Arbitration Database (PITAD).
} 
We begin in Sections 2 and 3 by problematizing existing definitions of environment-related cases in investment treaty arbitration and offering an alternative 'analytical' typology. In Section 4, we examine whether investment treaty arbitration is 'biased' against the environment by considering the outcomes of these cases relative to others. In Section 5, we examine 8 different features of investment treaty arbitrations involving an environmental component and evaluate outcome patterns for a more nuanced picture of what types of cases present the largest problems for domestic environmental protection. The article concludes with a future research agenda for empirically testing claims about the legitimacy of investment treaty arbitration in the context of disputes involving an environmental component.

\section{A Typology of Environment-Related Cases}

There are a number of ways in which an international investment treaty dispute can be considered an investment dispute involving an environmental component. One tendency in the current literature is to treat the environment as a descriptive category, denoting those cases in which the environment is a theme. For example, Viñuales defines an environment-related case as:

disputes that arise from the operations of investors (i) in environmental markets (e.g. land-filling, waste treatment, garbage collection, pesticides/chemicals, energy efficiency, emissions reduction, biodiversity compensation, etc.) and/or (ii) in other activities, where their impact on the environment or on certain minorities is part of the dispute (e.g. tourism, extractive industries, pesticides/chemicals, water extraction or distribution) and/or (iii) to disputes where the application of domestic or international environmental law is at stake. ${ }^{6}$

The result is a palette of cases (114 in total - which also includes pending cases) that include claimant-investor challenges to both pro-environmental and anti-environmental measures (such as the elimination of renewable energy subsidies) as well as cases in which concerns of environmental protection may not be central.

While this definition serves certain purposes (eg showing the breadth of cases that touch on environmental issues), we prefer to treat environmental issues in investment treaty arbitration as an analytical category. At least for the purposes of this article, we define an environmentrelated foreign investment dispute as:

treaty-based claims where the claimant-investor is challenging a domestic measure in the state where the investment is hosted and that measure is taken and justified by the respondent state, in whole or part, on the grounds of environmental conservation or protection.

We call this analytic category of disputes as 'environment-related' investment treaty arbitrations throughout this article. They are the complete universe of cases where the environment-related measure taken by the host state has been used as either a justification, defense or exception to the alleged breach of the applicable international investment agreement (IIA).

\footnotetext{
${ }^{6}$ Jorge Viñuales, 'Foreign Investment and the Environment in International Law: The Current State of Play’ in Kate Miles (n 4) ch 2.
} 
This focus on such domestic environment-related measures is well founded: it allows us to assess the legitimacy-related claim that states do not have sufficient policy space to (environmentally) regulate in the public interest. One of the most significant charges against the legitimacy of investment treaty arbitration is that arbitrators sitting in these types of cases will give short-shrift to a host state's environment-related justification for measures taken that negatively affect the profitability or existence of a foreign investor's investment. Moreover, we avoid the common risk that comes with descriptive categories - that they are used unknowingly as analytical categories. This is a real risk in the current legitimacy debates relating to investment treaty arbitration.

Our definition results in a smaller dataset of 49 cases that have been concluded through 1 August 2016. ${ }^{7}$ These investment treaty arbitrations range in the types of domestic measures that a host state has taken. They include the following broad categories: (1) refusal to renew or grant a license or permit based on an environmental justification; (2) modification or cancellation of a concession or contract based on an environmental justification; (3) environment-related temporary or permanent import bans on certain products; or (4) judicial decisions relating to domestic environment-related litigation. ${ }^{8}$ In all of these cases, some type of environment-related domestic measure forms the basis, in whole or part, of the claimantinvestor's claim that the respondent state violated its IIA obligations.

While we have attempted to be very clear and concise in what we are calling an environmentrelated investment treaty arbitration, it is also helpful to discuss a number of types of cases that we are not including, and to give reasons for these choices.

First, we do not include contract-based or foreign investment law-based arbitrations; rather, we focus exclusively on investment treaty-based arbitrations. We therefore do not include a few famous early cases that are almost always picked up in the literature, such as Santa Elena and $S P P .{ }^{9}$ Given the focus of this article on domestic measures relating to environmental protection in treaty-based cases, there are sound methodological reasons to not mix non-treaty cases with treaty cases. With only the exception of non-treaty based $\operatorname{ICSID}^{10}$ cases, the universe of non-treaty arbitrations with a respondent state party remain largely confidential and therefore providing a systematic assessment of these types of cases is nearly impossible; to cherry-pick the few cases that are publicly available would distort any attempt to provide an aggregative perspective, as we do here.

Second, we do not include cases that have arisen on the basis of environmental subject-matter exclusively. Prominent examples of these types of cases include, inter alia, those involving water service or waste management projects; but where the investment treaty dispute was unrelated to any domestic environment-related measure or where the respondent state bases no defense on an environmental protection justification. To include every case that theoretically could have some type of environmental justification by the state hosting the foreign investment, or that are vaguely related to the 'environment,' would explode the dataset to almost meaningless proportions. Almost every investment treaty arbitration registered to date can be seen to affect the human or physical environment in some way.

\footnotetext{
${ }^{7}$ Concluded cases include cases that were settled or discontinued. In the dataset, there is 1 discontinued case and 7 settled cases. See Section 3.2 below.

${ }^{8}$ More detail provided in Section 5.1 below.

${ }^{9}$ Compañia del Desarrollo de Santa Elena SA v Costa Rica, ICSID Case No ARB/96/1 (17 February 2000); Southern Pacific Properties (Middle East) Ltd v Egypt, ICSID Case No ARB/84/3, Award (20 May 1992).

${ }^{10}$ International Centre for the Settlement of Investment Disputes.
} 
However, for purposes of completeness and comparison, we will provide an analysis (in Section 5.6) of all cases involving a particular economic sector (ie all water and waste management related cases) and compare outcomes in these cases with those that meet our criteria of an environment-related investment treaty arbitration.

Third, in relation to cases with an environmental subject-matter, there is an additional category of cases that are not included: cases where the domestic measure taken (or a failure to act) by the host state causes injury to the foreign investor that is implementing an investment aimed at environmental protection or conservation. There are a number of pending cases that meet this criteria, but the most prominent examples of these types of cases that have already been resolved would be any case where the foreign investor has invested in projects aimed at the production of renewable energy and the host state's action or inaction reduces or prevents the foreign investor from producing renewable energy. There is a good argument that many of these cases involve domestic measures that are in fact detrimental to environmental protection (ie they hinder or reduce the production of energy from renewable sources).

Fourth, we do not include cases that are currently pending. In our PITAD dataset of all registered investment treaty arbitrations through 1 August 2016, there are 26 cases pending where it is known that the host state's justification for the domestic measure that is alleged to negatively affect the foreign investment is based, in whole or part, on environmental protection or conservation grounds. This does not include two pending cases where the host state's failure to provide adequate environmental protection to the foreign investment is the basis for the claim. ${ }^{11}$ Likewise, this list of 26 pending cases does not include the significant number of pending cases (50 cases) relating to production of renewable energy: 43 cases relating to the production of solar energy (either photo-voltaic (PV) or concentrated solar power (CSP)); 2 cases relating to wind energy production; 4 cases relating to production of hydro-energy; and 1 case relating to bio-mass energy production. ${ }^{12}$

Fifth, we do not include cases where the arbitration was never formally registered, but only a notice of intent to submit an arbitration was transmitted. ${ }^{13}$

Figure 1: Pending and concluded environment-related cases by registration year (74 cases)

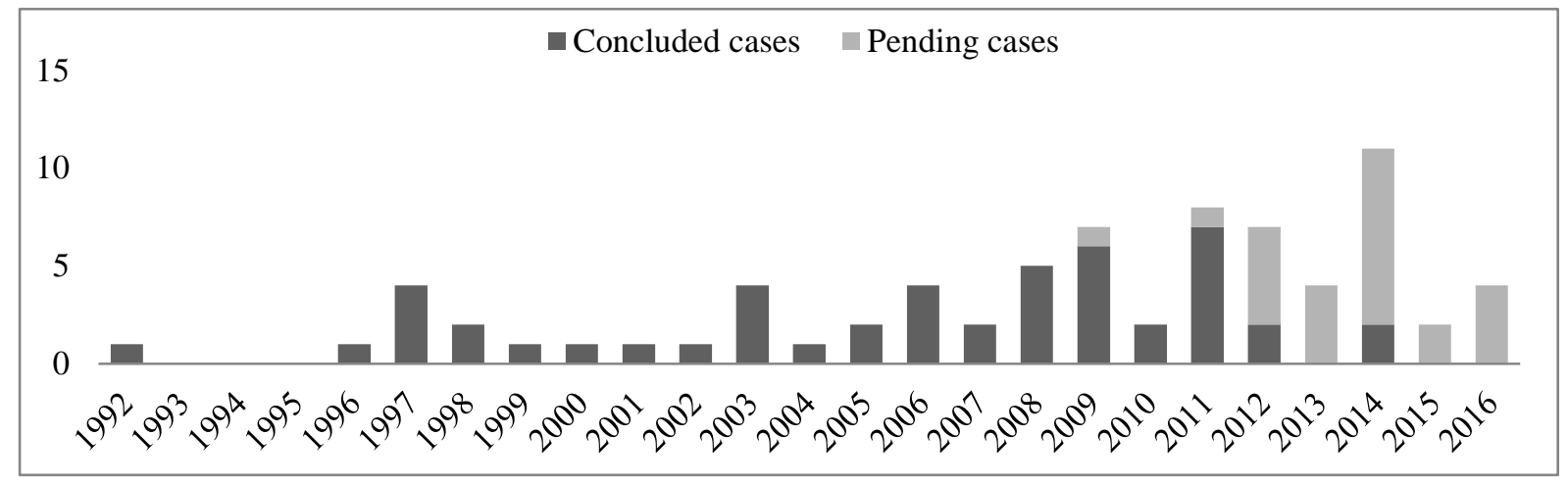

\footnotetext{
${ }^{11}$ Peter Allard $v$ Barbados, PCA Case No 2012-06, pending; Zelena NV and Energo-Zelena DOO Inđija $v$ Serbia, ICSID Case No. ARB/14/27, pending.

${ }^{12}$ For an assessment of these types of cases, see Daniel Behn and Ole Kristian Fauchald, 'Governments under Cross-Fire: Renewable Energy and International Economic Tribunals' (2015) 12(2) Manchester Journal of International Economic Law 117.

${ }^{13}$ See eg Sun Belt Water Inc v Canada, Notice of Intent to Arbitrate (27 November 1998).
} 


\section{Evaluating Challenges to Environment-Related Measures}

When and how often do the rights of claimant-investors trump a domestic environmentrelated measure in investment treaty arbitration? The majority of cases where the claimantinvestor was successful (21 cases in our dataset) relate to what the arbitral tribunal considered to be: (1) environment-related measures aimed at legitimizing or disguising the real aim or purpose of the host state's actions that were detrimental to the foreign investor ( 9 cases); or (2) environment-related measures that were substantively legitimate and justifiable (including direct expropriations) (6 cases), but where the host state's implementation of the measure (including the respondent state's failure to pay adequate compensation) violated the applicable IIA. ${ }^{14}$ It is this fact that led to the recent claim by Brower that:

[n]o investment tribunal has ever ordered a State to compensate an investor for simply enacting a generally applicable environmental law or for legitimately enforcing a regulation that caused an investor a loss. Very deferential standards have been applied to environmental regulatory measures. ${ }^{15}$

While Brower's statement is factually accurate, it fails to account for whether investment treaty arbitrators were deferential enough to respondent states in such cases. Critics of the outcomes in these cases would question whether it is ever the task of investment treaty arbitrators to question the 'legitimate' purpose of a domestically-enacted environmental law or regulation or to inquire as to whether such laws or regulation were 'legitimately' implemented or enforced. Thus, Brower's benchmark for evaluation may be inappropriate.

Taking the view that such a suspicious approach to the assessment of domestic environmentrelated measures by investment treaty arbitral tribunals can be problematic, Viñuales claims that this 'traditional approach' considers all conflicts between domestic environment-related measures and international investment law obligations as 'legitimacy conflicts:'

[t]he environmental measures adopted by host States were thus seen as 'suspicious' (unilateral protectionism in disguise) and in all events 'subordinated' to international (investment) law (by virtue of the rule that international law prevails over domestic law). This view, which may have reflected the specific factual configurations of some early cases, has sometimes been extrapolated to the assessment of genuinely environmental and even internationally-induced measures, with the unfortunate result that environmental considerations remained legally subordinated to purely economic considerations. ${ }^{16}$

This so-called traditional approach perfectly captures a fundamental, and oft-invoked, critique of investment treaty arbitrators in relation to environment-related cases: if given the opportunity, arbitral tribunals will find in favor of claimant-investors and subordinate legally sound domestic environment-related measures taken by respondent states on the basis that they are 'suspicious' in their intent, or - even if they are not - domestic measures that fail to

\footnotetext{
${ }^{14}$ The remaining 6 cases where the claimant-investor won on the merits include 4 cases dealing with environment-related counterclaims and 2 cases where the environment-related measure was unrelated to the breach of the IIA that was found. More detail is provided in Section 4.1 below.

${ }^{15}$ Charles Brower and Sadie Blanchard, 'From "Dealing in Virtue" to "Profiting from Injustice:" The Case against "Re-Statification” of Investment Dispute Settlement' 55(1) Harvard International Law Journal Online (2014) 45, 50.

${ }^{16}$ Viñuales (n 6) 14.
} 
meet international rule of law standards must always give way to the standards of treatment required by the applicable IIA.

An alternative to the traditional approach is what Viñuales calls the 'progressive approach,' which he defines as an approach that would consider all conflicts between domestic environment-related measures and international investment-related obligations as 'normative conflicts:'

[u]nder this view, most domestic environmental measures would be seen as required or justified by environmental treaties, hence standing on an equal footing with other international norms (such as investment disciplines) and reflecting multilateral action (defeating the suspicion of unilateral protectionism). This view would, in fact, apply a different set of conflict rules to different types of conflicts ('legitimacy' and 'normative' conflicts) and, more generally, defuse the suspicion and mistrust that some tribunals still see, despite the rise of environmental awareness at the global level, as the starting-point in the analysis of environmental regulation. ${ }^{17}$

While Viñuales holds that there is some evidence of this more progressive approach being applied by arbitral tribunals, he is more convinced by what he calls the 'upgraded traditional' approach whereby arbitral tribunals look at the domestic environment-related measure with less suspicion, and while there has not been a full embrace of the progressive approach, some arbitral tribunals in environment-related cases do appear to be increasingly sensitive to environment-related issues in investment treaty arbitration.

Whether or not there has been an identifiable shift in arbitrator behavior is taken up in the last part of the article. In following section, we look at a number of factors that could assist in identifying the types of environment-related cases that might be seen to apply either the traditional, upgraded, or progressive approach and that raise concerns that investment treaty arbitration (and the broader international investment regime) is insensitive to environmental concerns. We use both an inductive approach using descriptive statistics and regression analyses.

\section{Cases by Outcome}

We now turn to apply Viñuales's benchmarks to various outcomes in environment-related cases, asking whether the traditional, upgraded, or progressive approach dominates. Table 1 below breaks down investment treaty arbitrations according to their eventual outcomes for environment-related cases (left column) and all investment treaty arbitrations to date (right column). ${ }^{18}$ Of the 49 concluded environment-related cases in our dataset, 7 were settled and 1 case was discontinued. Removing these cases, the number of fully resolved ${ }^{19}$ cases drops to 41 cases. In these cases, the claimant-investor won on the merits in 21 , lost on jurisdiction in 9 and lost on the merits in 11 - here we define a claimant-investor win as at least a partial win. $^{20}$ Thus, claimant-investors have succeeded in a very slim majority of finally resolved

\footnotetext{
${ }^{17}$ Ibid 16.

${ }^{18}$ Through 1 August 2016. For a complete list of the cases, see Annex I.

${ }^{19}$ A fully resolved case is counted as where the claimant-investor wins on the merits or where the claimantinvestor loses on jurisdiction or the merits.

${ }^{20} \mathrm{~A}$ full and partial win are not categorized according to the ratio of amount claimed and awarded or the number of successful claims. Rather, the distinction between full win and partial win is based on whether the claimantinvestor - in a holistic assessment of the case - was made whole by the arbitral tribunal.
} 
environment-related investment treaty arbitrations (21 against 20). In this section we drill down on these patterns, compare outcomes with the overall caseload, descriptively assess changes in outcomes across time, and examine compensation differentials.

Table 1: Overall win-loss percentages for environment-related cases

\begin{tabular}{l|c|c|c|c|} 
& \multicolumn{2}{|c|}{ Environment-related cases } & \multicolumn{2}{|c|}{ All cases } \\
Outcome & Percentage & Cases & Percentage & Cases \\
\hline Investor wins on the merits & $43 \%$ & 21 & $31 \%$ & 161 \\
Investor loses on jurisdiction & $23 \%$ & 9 & $17 \%$ & 88 \\
Investor loses on the merits & $18 \%$ & 11 & $19 \%$ & 96 \\
Case settled & $14 \%$ & 7 & $22 \%$ & 115 \\
Case discontinued & $2 \%$ & 1 & $11 \%$ & 54 \\
\hline Total & $100 \%$ & $\mathbf{4 9}$ & $100 \%$ & $\mathbf{5 1 5}$ \\
\hline
\end{tabular}

\subsection{Patterns in Case Outcomes}

Turning to the different types of case outcomes, we begin with the 8 environment-related cases that were either settled or discontinued. This sub-set of outcomes constitutes about $14 \%$ of all environment-related cases. ${ }^{21}$ However, as can be seen in Table 1 above, this is slightly less than the percentage of settled or discontinued cases in the entire dataset of 515 concluded cases in our dataset (22\%). Nonetheless, settled cases tend to raise questions about regulatory chill and whether the respondent state agreed to settle the case by forgoing its domestic environmental measures. At least in the context of our dataset, there are a few cases where there are claims that this has occurred, ${ }^{22}$ but is countered by the majority of environmentrelated cases where no evidence of that specific kind of regulatory chill is present.

Turning to investigate the fully resolved cases in the dataset, it is notable that the claimantinvestor lost in 9 cases at the jurisdictional stage of the dispute. ${ }^{23}$ As such, none of these cases evaluated whether the respondent state's environment-related measure violated the substantive provisions of the applicable IIA. This raises a question of whether environmentrelated measures might have been at risk had the claimant-investor overcome procedural obstacles. Thus, it might be argued that these cases cannot be interpreted as real 'wins for the environment' - another foreign investor might have survived the jurisdictional challenge. Yet, it may be conceivable to contend that some jurisdictional decisions did incorporate environmental sensitivity. By rejecting these cases at the jurisdictional stage, these arbitral tribunals may have been attempting to avoid having to rule on the merits of the case, saving themselves from having to rule against a legitimate environment-related measure. At least, 3 environment-related investment treaty arbitrations potentially fall into this 'hard case' category. $^{24}$

On the merits, the claimant-investor won in 21 instances and lost in 11 instances. In other words, if the claimant-investor is able to pass the jurisdictional hurdle in an environmentrelated investment treaty arbitration, the win rate is $66 \%$ for all cases reaching the merits stage

\footnotetext{
${ }^{21}$ See cases in Annex I labeled 'case settled' or 'case discontinued.'

${ }^{22}$ See eg Ethyl Corp v Canada, UNCITRAL, settled; Vattenfall and Others $v$ Germany (Vattenfall I), ICSID Case No. ARB/09/6, settled.

${ }^{23}$ See cases in Annex I where 'claimant loses on jurisdiction.'

${ }^{24}$ See eg Industria Nacional de Alimentos SA and Indalsa Perú SA (formerly Empresas Lucchetti SA and Lucchetti Perú SA) v Peru, ICSID Case No ARB/03/4, Award (7 February 2005); Commerce Group Corp and San Sebastian Gold Mines Inc v El Salvador, Award, ICSID Case No ARB/09/17, Award (14 March 2011).
} 
of the dispute. Of the 11 cases where the claimant-investor lost on the merits, we find that in all of the cases, the domestic environment-related measure taken by the respondent state was legitimately justified and implemented; and that the arbitral tribunal explicitly held that these measures did not breach any provisions of the IIA. ${ }^{25}$ Furthermore, it is important to note that in all of these cases, the environment-related measure and its relation to the foreign investment was central - as opposed to merely incidental - to a finding that the host state did not breach the applicable IIA.

The conclusion that can be drawn from these 11 cases is that the arbitral tribunal did not give short shrift to the environment-related justification and that - at least in these cases - the property rights of the claimant-investor did not trump the need of the respondent state to take measures aimed at protecting the environment in the public interest. They appear to fall within Viñuales's progressive approach. On the other hand, in the 21 cases where the claimantinvestor won on the merits (which is a $12 \%$ higher success rate than the overall caseload), ${ }^{26}$ many of these cases might fall into Viñuales's traditional approach where investment treaty arbitral tribunals viewed the challenged domestic environment-related measure as suspicious. Of these 21 cases, the domestic environment-related measure taken by the respondent fit broadly into 4 categories where the arbitral tribunal found that:

(1) the domestic environment-related measure taken by the host state was being used to disguise or legitimize the actual action or measures that negatively affected the foreign investor's investment (9 cases);

(2) implementation of an otherwise legitimate or justifiable environment-related measure by the host state failed on major procedural defect grounds and breached the foreign investor's rights under the applicable IIA (6 cases);

(3) a counterclaim or finding of contributory negligence on environment-related grounds that off-set or could have off-set the claimant-investor's compensation award (4 cases); ${ }^{27}$ or

(4) the environment-related measure taken by the host state was present in the case, but was inconsequential or unrelated to the breach of the IIA (2 cases). ${ }^{28}$

Looking at the overall caseload outcomes in environment-related cases, we find a mixed picture. On one hand, environment-related cases settle less frequently than all other investment treaty arbitrations, and claimant-investors win in approximately half of the cases (which is just slightly better than the win rates for all cases (47\%)). On the other hand, a significant number (23\%) of environment-related cases never reach the merits (ie they are dismissed on jurisdictional grounds), environment-related cases where the claimant-investor loses on the merits have all been successfully defended by respondent states on environment-

\footnotetext{
${ }^{25}$ See cases in Annex I where 'claimant loses on the merits.'

${ }^{26}$ See cases in Annex I where 'claimant wins on the merits.'

${ }^{27}$ Burlington Resources Inc v Ecuador, ICSID Case No ARB/08/5, Decision on Liability (14 December 2014); Perenco Ecuador Ltd v Ecuador, ICSID Case No ARB/08/6, Decision on Remaining Issues of Jurisdiction and on Liability (12 September 2014); Sergei Paushok, CJSC Golden East Co and CJSC Vostokneftegaz Co v Mongolia, UNCITRAL, Award on Jurisdiction and Liability (28 April 2011); Copper Mesa Mining Corp v Ecuador, PCA Case No 2012-2, Award (15 March 2016).

${ }^{28}$ Emilio Agustín Maffezini v Spain, ICSID Case No ARB/97/7, Award (13 November 2000); Chevron Corp and Texaco Petroleum Co v Ecuador (Chevron I), PCA Case No 34877, Final Award (31 August 2011).
} 
related grounds. Moreover, in cases where the claimant-investor wins on the merits, almost all of the arbitral tribunals in these cases have held that the respondent states could not rely on the environmental justification because it was either viewed suspicious in terms of its intent or it failed to meet basic procedural rule of law standards in its application or implementation vis-à-vis the foreign investor.

\subsection{Comparison with Overall Caseload}

In Table 2 below, we set out a multivariate regression analysis to determine if there is a statistically significant relationship between win-loss percentages in environment-related cases and all other investment treaty arbitrations. This analysis includes a bivariate analysis (Models 1 and 4) and a multivariate analysis with controls (Models 2 and 5) and only controls (Models 3 and 6). We split the analyses by Any Win (either a partial or full win on the merits is counted) or Full Win (only a full win on the merits is counted).

We include a series of dummy variables from previous work in analyzing patterns in investment treaty arbitration, ${ }^{29}$ which control for different structural features that we believe might influence outcomes in investment treaty arbitrations. First, we include a dummy variable for treaty-based arbitration type, specifically NAFTA-based Cases and ICSIDadministered Cases. Second, we apply an Extractive Industry Cases dummy variable measuring whether the case arises out the extractive industries economic sector. Third, we add a measure of Law Firm Advantage to control for the effect of the quality (or at least the expense) of legal counsel. ${ }^{30}$ Fourth, we include a variable for State Learning to control for the effect of previous exposure to investment treaty arbitration. ${ }^{31}$ Fifth, to control for situations where specific events or circumstances create an artificially large caseload against a respondent state in a short space of time, we use a Case Cluster dummy. ${ }^{32}$ Finally, we include logged GDP per capita of respondent states as a control for a number of factors. With Berge, we have demonstrated that claimant-investors are less likely to win against states with higher GDP per capita, and regardless of the level of their democratic governance. ${ }^{33}$

As Table 2 below demonstrates, there is no statistically significant difference in outcomes in environment-related cases as compared with the overall caseload of fully resolved investment treaty arbitrations (Models 1 and 4). However, we see that the coefficient for environmentrelated cases outcomes is positive (indicating a higher chance of claimant-investor success in environment-related cases versus all investment treaty arbitrations) in both the bivariate and multivariate analysis; and in the multivariate analysis for Full Wins, the coefficient is

\footnotetext{
${ }^{29}$ Malcolm Langford and Daniel Behn, 'Managing Backlash: The Evolving Investment Treaty Arbitrator' European Journal of International Law (2016).

${ }^{30}$ The index takes the value of (1) if only the claimant-investor counsel is from a Global 100 law firm; (-1) if only the respondent state retains a Global 100 law firm; or (0) if both the claimant-investor and the respondent state both have the same type of law firm representing them. A Global 100 law firm is defined according to: American Lawyer <http://www.americanlawyer.com/id=1202471809600/2015-Global-100-TopGrossing-LawFirms-in-the-World $>$ accessed 1 August 2016.

${ }^{31}$ We assume the marginal effect of respondent state learning to diminish over time, and code how many cases any given respondent state has had filed against it at the time of case registration up until the tenth case.

${ }^{32}$ The Case Cluster dummy takes the value (1) if a respondent state has had five or more cases registered against it in a given year, and (0) otherwise. The case clusters in the full set of cases registered are: Argentina (2002, 2003, 2004), Czech Republic (2005), Ukraine (2008), Egypt (2011), and Venezuela (2011, 2012).

${ }^{33}$ Daniel Behn, Tarald Berge, and Malcolm Langford, 'Poor States or Poor Governance: Explaining Outcomes in Investment Treaty Arbitration’ SSRN Working Paper (2016) <http://papers.ssrn.com/sol3/Papers.cfm?abstract_ id=2740 516> accessed 1 August 2016.
} 
statistically significant at the $10 \%$ level. Given the lack of strong statistical significance, we cannot really read anything into the difference between environment-related cases and the overall caseload of investment treaty arbitration.

Table 2: Logit Regression of Differences in Environment-Related Case Outcomes

\begin{tabular}{l|c|c|c|c|c|c|} 
& \multicolumn{3}{|c|}{ Any Win } & \multicolumn{3}{c|}{ Full Win } \\
\cline { 2 - 7 } & $\begin{array}{c}\text { Model 1 } \\
\text { Bivariate }\end{array}$ & $\begin{array}{c}\text { Model 2 } \\
\text { With } \\
\text { Controls }\end{array}$ & $\begin{array}{c}\text { Model 3 } \\
\text { Only } \\
\text { Controls }\end{array}$ & $\begin{array}{c}\text { Model 4 } \\
\text { Bivariate }\end{array}$ & $\begin{array}{c}\text { Model 5 } \\
\text { With } \\
\text { Controls }\end{array}$ & $\begin{array}{c}\text { Model 6 } \\
\text { Only } \\
\text { Controls }\end{array}$ \\
\hline Environment-related Cases & $\mathbf{0 . 1 0}$ & $\mathbf{0 . 3 2}$ & & $\mathbf{0 . 4 3}$ & $\mathbf{0 . 7 3 *}$ & \\
NAFTA-based Cases & & -0.55 & -0.51 & & $-1.57^{* *}$ & $-1.50 *$ \\
ICSID-administered Cases & & -0.25 & -0.23 & & $-0,09$ & -0.04 \\
Extractive Industry Cases & & $0.55^{*}$ & $0.61^{* *}$ & & 0.16 & 0.30 \\
State Learning & & 0.01 & 0.01 & & $0.078^{*}$ & 0.08 \\
Case Clusters & & 0.62 & 0.60 & & 0.10 & 0.05 \\
Law Firm Advantage & & $0.51^{* *}$ & $0.50^{* *}$ & & 0.28 & 0.25 \\
GDP per capita & & $-0.36^{* * *}$ & $-0.35^{* * *}$ & & $-0.30^{* *}$ & $-0.27^{* *}$ \\
\hline Chi-sq & 0.09 & 35.58 & 34.79 & 1.36 & 21.38 & 18.11 \\
\hline $\mathrm{N}$ & 341 & 343 & 341 & 341 & 343 & 341 \\
\hline$* \mathrm{p}<.10 ; * * \mathrm{p}<.05 ; * * * \mathrm{p}<.01$ & & & & & \\
\hline
\end{tabular}

However, Model 3 provides an indication of why the level of claimant-investor wins might be higher in environment-related cases. The coefficient for Extractive Industry Cases is much higher and statistically significant when environment-related cases are not included. The two are in fact highly correlated. A covariance test confirms significant covariance - indicating a partial overlap between environment-related and extractive industry related cases. ${ }^{34}$ Thus, the higher claimant-investor success rates in environment-related cases may be driven by the fact that many of these environment-related cases involve the extractive industries sector (15 cases). We have hypothesized previously that this higher success rate is not that surprising when one considers that many of these cases focus primary on the levels of compensation relating to (direct) expropriations rather than determinations of liability relating to other provisions of a relevant IIA. ${ }^{35}$

\subsection{Time and Reflexivity}

In this sub-section, we briefly explore whether there has been a shift in the behavior of investment treaty arbitrators that would signal that there is a greening of investment treaty arbitration across time. In other words, is there evidence that investment treaty arbitrators are re-balancing decisions in investment treaty arbitration in a manner that would show more deference towards respondent states and their environmental policies in environment-related cases? While we look at different factors that might affect outcome in environment-related cases in the next section, here we will look as to whether we can identify a general trend shift in outcomes in environment-related cases across time.

Looking at the time trend of the 41 fully resolved investment treaty arbitrations involving a challenge to a domestic environment-related measure, three points are most relevant. First, the number of cases resolved prior to 2005 are extremely limited (nine cases) and in these cases,

\footnotetext{
${ }^{34}$ Chi-sq $=13.41$ and the positive relationship is significant at the $1 \%$ level.

${ }^{35}$ Behn, Berge, and Langford (n 33).
} 
the claimant-investor had a very high success rate (89\%). Second, in the period of 2005 through about 2010, the number of cases resolved annually increases but the success rate for claimant-investors in these cases drops significantly (18\%). Third, in the period of 2011 through to the present, the annual number of resolved cases averages about 4 cases per year and the success rate for claimant-investors is about $52 \%$. We can therefore look at the graph in Figure 5 below and assert that environment-related cases have been increasingly annually, that early cases produced a lot of wins for claimant-investors followed by a period of relatively low claimant-investor success and culminating in what appears to be a fairly balanced win-loss ratio for claimant-investors in the past 5 years.

Figure 5: Win-loss percentages and number of disputes resolved per year (41 cases)

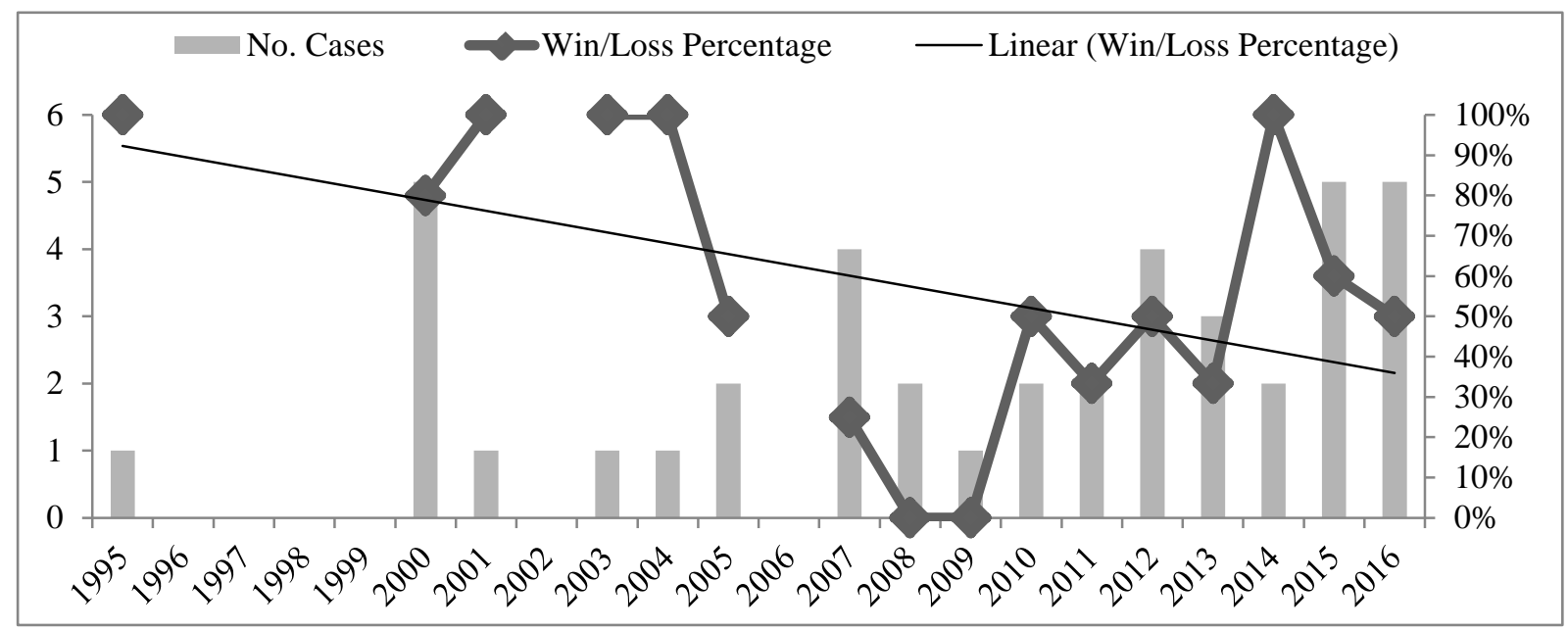

These are dramatic differences in the win-loss rates for these types of environment-related cases across time. It appears that there was a severe correction (possibly an over-correction) during the period of 2005 to 2010, after the earlier period (1995 to 2004) where claimantinvestors won almost every environment-related cases that they brought. It could be that these shifts in the win-loss patterns are unrelated to shifts in arbitrator behavior and that they can be attributed to the factual scenarios of each individual case, but the empirical evidence strongly suggests that such a drastic shift cannot be attributed to pure chance. It is very likely that arbitrators themselves played a role in the dramatic re-balancing of win rates for claimantinvestors in cases after 2004.

\subsection{Levels of Compensation Awarded}

Turning finally to the levels of compensation, there are 18 environment-related cases where the amount of compensation awarded is known, ${ }^{36}$ and arbitral tribunals have awarded winning claimant-investors a total of 2837716287 US dollars (USD) in damages. This is a staggering amount, but becomes relatively more modest if one removes the 2 recent mining concession expropriation cases against Venezuela. These 2 cases resulted in damage awards totaling $1386000000 \mathrm{USD}^{37}$ and $713032000 \mathrm{USD}^{38}{ }^{38}$ respectively. Of the remaining 16 cases where the amount of compensation awarded is known, claimant-investors were awarded at total of

\footnotetext{
${ }^{36}$ In 4 cases, a final damage award is still pending as of 1 August 2016; and in 1 case, the amount of damages remains unknown.

${ }^{37}$ Crystallex International Corp v Venezuela, ICSID Case No ARB (AF)/11/2, Award (20 July 2016).

${ }^{38}$ Gold Reserve Inc v Venezuela, ICSID Case No ARB(AF)/09/1, Award (22 September 2014).
} 
733961782 USD in damages with an average of 52425842 USD per case. However, as Figure 2 below demonstrates, 44\% of the cases have awarded less than 10 million USD in damages in cases where the claimant-investor won. In all 18 cases, the ratio of the compensation awarded to the amount of compensation claimed is $43 \%$. This ratio is slightly higher than the compensation ratio for all investment treaty arbitrations resolved to date (38\%).

Figure 2: Environment-related cases by compensation awarded (18 cases)

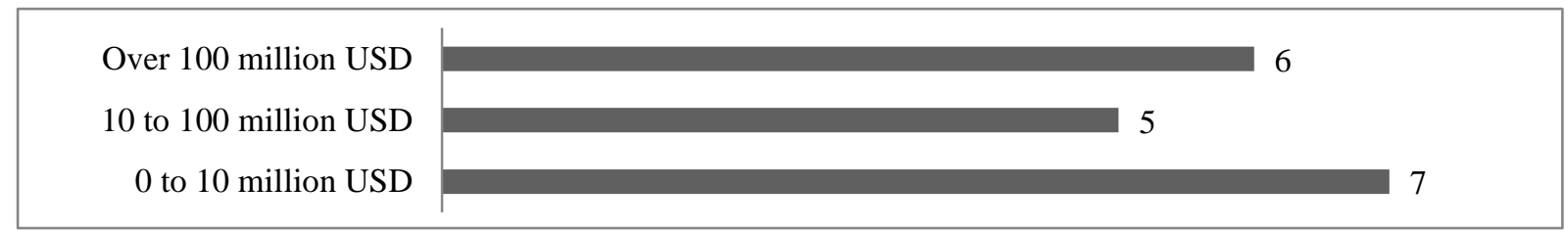

As to the impact of the levels of compensation on environment-related measures, we find that almost all of the cases where the claimant-investor wins on the merits and is awarded significant amounts of compensation came in cases where the arbitral tribunal found a violation of the expropriation (both direct and indirect) standard. These are all cases where the arbitral tribunal found that the entire value of the foreign investor's investment was destroyed, made useless or directly expropriated. On the other hand, in the 35\% of the environmentrelated cases where there was no finding of expropriation, but where a violation of the fair and equitable treatment (FET) standard was found, the levels of compensation tended to be significantly lower. ${ }^{39}$

Further, it must be noted that in none of the environment-related cases did an arbitral tribunal order non-pecuniary restitution. In other words, there was no single case where a losing respondent state was required to revoke or change its environment-related policies; rather, they only had to pay compensation for the injuries suffered by the foreign investor under the relevant IIA. This is important in considering whether investment treaty arbitration is having a negative impact on a state's need to protect its environment. While unpleasant to be hit with a losing investment treaty arbitration that requires the payment of significant amounts of compensation, there is no evidence that - to date - investment treaty arbitration decision has directly impeded a state from pursuing and implementing measures that it deems necessary for the protection of the environment.

However, even if we do not find evidence of an investment treaty arbitration having a direct effect on a state's ability to regulate, it is still an open question as to whether all of these cases, in both the aggregate and at the individual level, might be having a chilling effect on the regulation of domestic environment-related policies. Indeed, we know from research on the impacts of domestic court judgments that indirect effects can sometimes be much greater than direct effects. ${ }^{40}$ This issue is difficult to assess empirically. There are a few case where a good argument can be made that a particular case had a chilling effect on the regulatory behavior of states, but it is too early to conclude with available evidence that the regulatory prerogatives of a host state have been systematically chilled in the face of investment treaty arbitrations where the claimant-investor is challenging a state's environment-related measures.

\footnotetext{
${ }^{39}$ See section 5.5 below.

40 See overview of literature in Malcolm Langford, Cesar Rodriguez-Garavito and Julieta Rossi, Social Rights Judgments and the Politics of Compliance: Making it Stick (CUP 2016).
} 


\section{Structural Factors}

We now turn to an examination of various structural, legal, and procedural factors which we believe are relevant to considering the sensitivity of investment treaty arbitration to environmental concerns. This covers the: (1) effect of the domestic measure; (2) legal status of the domestic measure; (3) level of domestic government involved; (4) type of treaty breach; (5) nature of the treaty provision; (6) economic sector involved; (7) respondent state characteristics; and (8) arbitrators and legal counsel. Because the sample size is modest we have adopted a medium- $\mathrm{N}$ approach, parsing the descriptive statistics in the qualitative context of the cases. However, in the final part of this section, we run a multivariate logit regression analysis of the different factors in order to identify whether there are any statistically significant differences in outcomes across the various combinations of factors that are present in environment-related investment treaty arbitrations.

\subsection{Effect of the Domestic Measure}

We begin by looking at what type of effect the domestic environment-related measure or measures taken by the host state has on the foreign investment. There is considerable variation in how the domestic measure effects the foreign investment in environment-related cases and significant differences that these effects have on win-loss outcome percentages for claimantinvestors: certain types of measures appear to be more problematic for host states than others. In the 45 cases where the effect of the domestic measure is known, there are 4 types of cases: ${ }^{41}$

(1) cases related to a refusal to renew or grant a license or permit based on an environmental justification (12 cases, claimant-investor wins 36\%);

(2) cases related to a modification or cancellation of a concession or contract based on an environmental justification (20 cases, claimant-investor wins 70\%);

(3) cases related to an environment-related temporary or permanent import ban on certain products (10 cases, claimant-investor wins $20 \%$ ); and

(4) cases related to judicial decisions relating to domestic environment-related litigation (3 cases, claimant-investor wins 33\%).

The picture of win-loss ratios for these different categories are revealing. Generally speaking, cases involving the modification or cancellation of concessions or contracts (primarily in the extractive industry sector) have a very high incidence of claimant-investor success $(70 \%)$, while cases involving environmentally justified bans on certain products have very low instances of success (20\%).

Figure 3: Effect of the domestic measure on the foreign investment (45 cases)

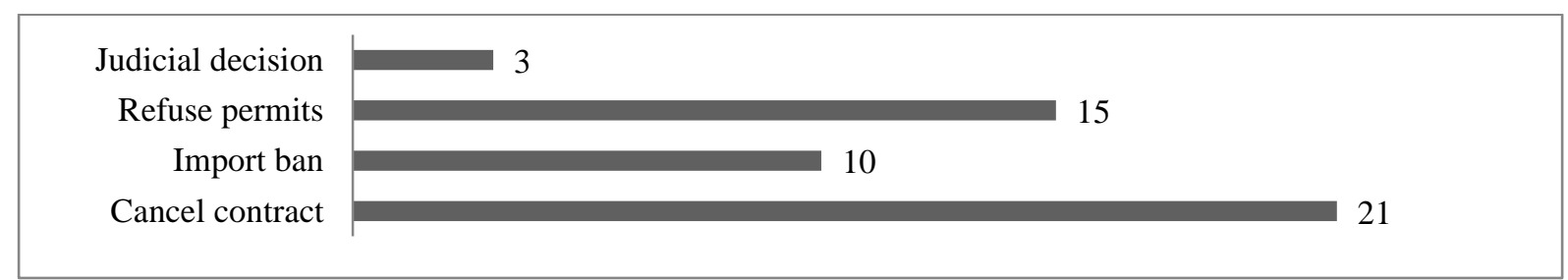

${ }^{41}$ In 4 of the cases, the type of domestic measure and its effect on the foreign investment is unknown. 
While extractive industry related cases are often responsible for significant environmental harm, the relationship between the type of effect that a domestic measure has on the foreign investment and outcomes in these cases is important. It may not be without reason that investment treaty arbitrators are more skeptical or suspicious of actions taken by host states that are directed at individual foreign investors (eg modifications or cancellations of contracts or concessions) in comparison to general bans on particular products or decisions made as part of existing legislative-mandated processes (eg licenses or permits).

Figure 4: Specific versus general measures in environment-related cases (45 cases)

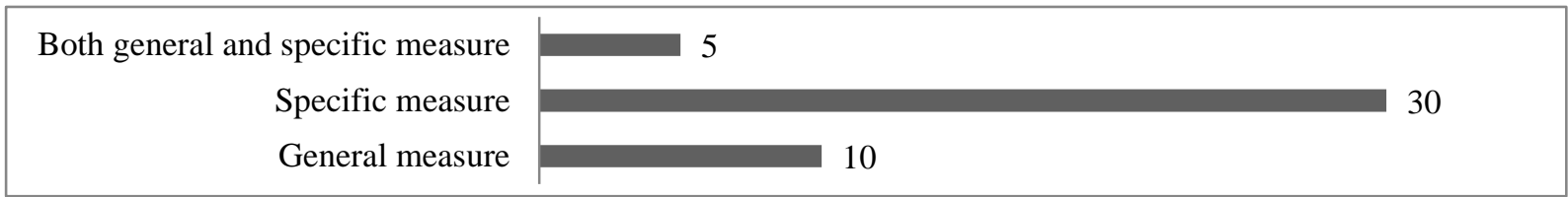

If we look at whether the challenged measure is specific to the particular foreign investor bringing suit or whether it is a measure that is generally applicable (Figure 4 above), we do find that the majority of environment-related cases involve specific measures targeting particular foreign investments (67\%), and that claimant-investor win rates are much higher in environment-related cases arising out of specific (to the particular foreign investor's investment) domestic measures (47\%) versus generally applicable domestic measures (11\%).

\subsection{Legal Status of the Domestic Measure}

A particular critique of investment treaty arbitration is that it favors the protection of foreign investor's rights to the detriment of generally applicable legislation passed by democratically elected governments in the public interest. It resembles the broader critique of judicial review and the legitimacy of invalidating legislative measures. ${ }^{42}$ One of the more profound findings in our dataset is that this notion about the type of measures being challenged in investment treaty arbitration (at least in environment-related cases) just does not - descriptively speaking - hold up on average.

Figure 5: Branch of government where the domestic measure originates (45 cases)

\begin{tabular}{|r|r|}
\hline Judicial branch action & 3 \\
Legislative branch action & 4 \\
Executive branch action &
\end{tabular}

As can be seen from Figure 5 below, the vast majority of measures taken by host state's originate in the executive branch of the government, often at the ministerial or administrative agency level (84\%). Only 4 cases out of the 45 cases (in 4 cases the status of the domestic measure is unknown) in our dataset can be said to have been a challenge to a legislative act ${ }^{43}$ and most importantly, the claimant-investor has won none of these cases. The remainder of cases came from the judicial branch (6\%).

\footnotetext{
${ }^{42}$ Jeremy Waldron, 'The Core of the Case Against Judicial Review' 115 The Yale Law Journal (2015) 13461406.

${ }^{43}$ Plama Consortium Ltd v Bulgaria, ICSID Case No ARB/03/24, Award (27 August 2008); Vito G Gallo v Canada, UNCITRAL, Award (15 September 2011); Yuri Bogdanov and Yulia Bogdanova v Moldova (Bogdanov IV), SCC Case No V091/2012, Award (16 April 2013); Ethyl Corp v Canada (n 22).
} 


\subsection{Level of Domestic Government Involved}

In addition to looking at where the domestic measure originates, it is also important to consider whether the measure is initiated by a national or sub-national governmental body. Many environment-related cases involve domestic measures that originate at the municipal or sub-national level (40\%). In many ways, this makes sense. While domestic environmentrelated measures or regulations do often originate through national administrative agencies or national legislative, the fact that so many cases of these environment-related cases are both specific to the particular foreign investor (Figure 4 above) and that they originate out of the executive branch of the government (Figure 5 above), it is expected to have a high number of environment-related cases that would arise out of very specific NIMBY (not in my backyard) scenarios where there is a localized environmental backlash and municipal governments are pushed to target and act against particular foreign investment projects that the public opposes. Interestingly, there is only one case in the dataset where the local measure is not a decision from the executive branch of government (ie a local legislative measure). ${ }^{44}$

Figure 6: Level of government measure in environment-related cases (45 cases)

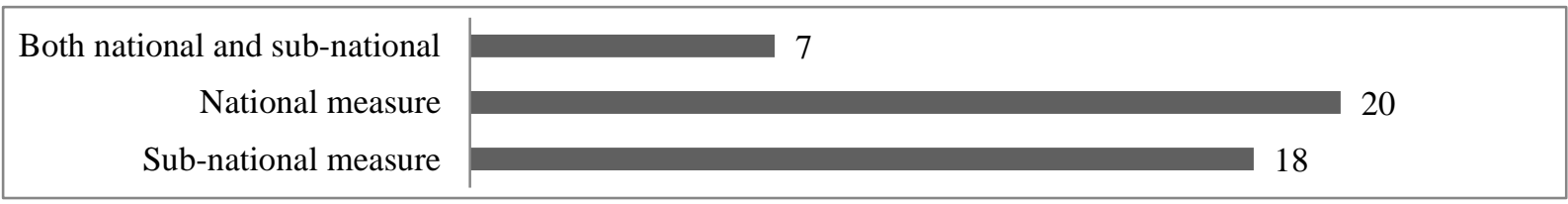

If the explanation for the high instance of cases arising out of municipal or sub-national environment-related measures is sound, then we would expect many of these cases to have involved various incarnations of public backlash, often exemplified by public protests. And this is exactly what we find. As can be seen form Figure 7 below, about $43 \%$ of the environment-related cases in the dataset include evidence of a backlash against particular foreign investment projects in the form of public protests. But if one looks just at the cases originating out of municipal or sub-national measures, the incidence of public protests rises to almost $60 \%$. Including the cases where the measure is specific to the foreign investment project and the measure originates at the municipal or sub-national level, the incidence of public protests relating to foreign investment projects rises even higher to $71 \%$. Interestingly, however, while there is a strong correlation between the type of measure taken and the likelihood that the governmental measure is - at least in part - responding to a localized public outcry, these public protests do not appear to have an affect on outcome. Claimantinvestors do no better or worse in these types of cases than the statistical win-loss percentages in all environment-related cases.

Finally, we examine two other factors that feature prominently in environment-related investment treaty arbitrations that might have an influence on outcome: the presence of an environmental impact assessment (EIA) process in the factual record of the case and the incidence of some type of domestic or local remedy pursued by the claimant-investor prior to the initiation of the investment treaty arbitration. For cases involving an EIA process in relation to the foreign investment, there is no appreciable difference in the win-loss ratios for claimant-investors as compared to the overall win-loss percentages for all environmentrelated cases. However, if we look at the sub-category of cases where the basis of the claim was the refusal of a permit, we find that EIA processes featured in $78 \%$ of these cases; but

\footnotetext{
${ }^{44}$ Gallo, ibid.
} 
again, the win-loss percentages in these cases do not deviate from the overall percentages for all environment-related cases.

Figure 7: Other measure-related factors in environment-related cases
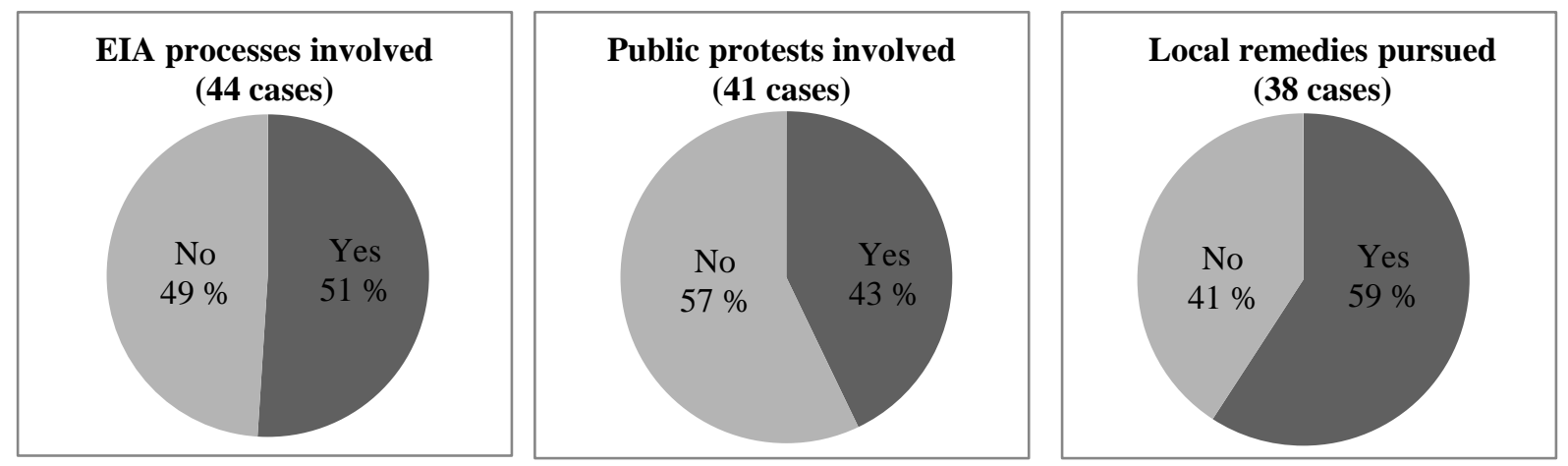

Turning to the issue of domestic remedies, we find a surprisingly high incidence of attempts by claimant-investors to find solutions to their disputes at the domestic level prior to the initiation of investment treaty arbitration. This finding challenges the idea that claimantinvestors who choose to use investment treaty arbitration do so in an effort to completely bypass opportunities to resolve their dispute at the domestic level in the first instance. However, while there is a substantial incidence of local remedies being pursued, there does not appear to be any deviations from the overall win-loss percentages. Descriptively, whether a claimant-investor pursues local remedies in an environment-related case before turning to investment treaty arbitration does not increase or decrease the chances that the foreign investor will be successful with their claim.

\subsection{Type of Treaty Breach}

In this section, we look at the types of treaties that are commonly invoked in environmentrelated investment treaty arbitrations; and the type of institution chosen to administer the dispute. Overall, as can be determined from Figure 8 below, the majority of environmentrelated cases involve the invocation of a bilateral investment treaty (BIT) (55\%) and are administered by ICSID (57\%). However, there is a large percentage of environment-related cases that involve NAFTA ${ }^{45}(27 \%)$ and that are administered according to the UNCITRAL ${ }^{46}$ arbitration rules (ad hoc arbitrations, 29\% and PCA-administered arbitration, ${ }^{47} 12 \%$ ). There do not appear to be any deviations from the overall win-loss rates for foreign investors as based on the type of institution chosen to administer the dispute.

Figure 8: Environment-related cases by treaty and institution (49 cases)

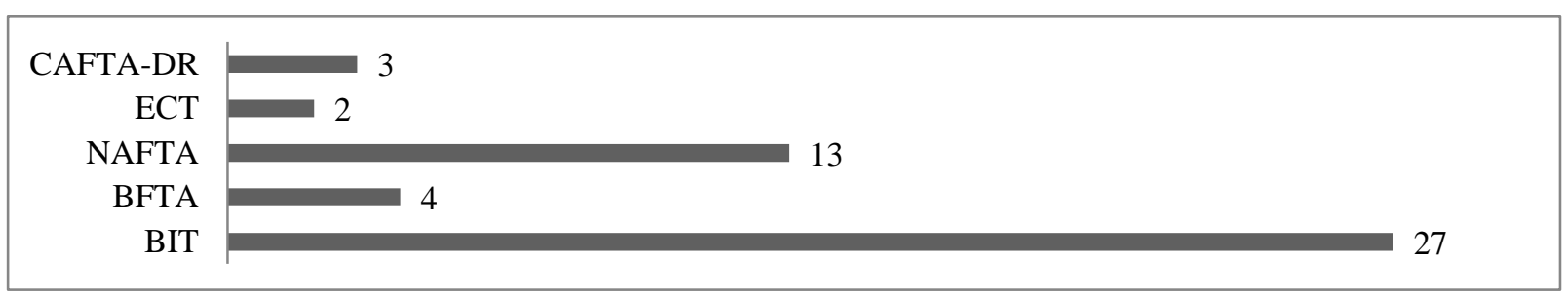

\footnotetext{
${ }^{45}$ North American Free Trade Agreement.

${ }^{46}$ United Nations Commission on International Trade Law.

${ }^{47}$ Permanent Court of Arbitration.
} 
UNCITRAL

SCC

PCA

ICSID

However, the type of treaty does seem to have an effect on outcomes in environment-related cases. For the NAFTA cases (Table 2 below), the overall win-loss percentages for claimantinvestors in environment-related cases (23\%) are higher than for all other NAFTA cases (17\%), but much lower than the win-loss percentage for claimant-investors for all environment-related cases (43\%) and for all investment treaty arbitrations to date (31\%) (see Table 1 above).

Table 2: NAFTA-based environment-related cases

\begin{tabular}{l|c|c|c|c|} 
& \multicolumn{2}{|c|}{$\begin{array}{c}\text { Environment-related cases } \\
\text { Percentage }\end{array}$} & \multicolumn{2}{c|}{$\begin{array}{c}\text { All other NAFTA cases } \\
\text { Oercentage }\end{array}$} \\
\hline Outcome & $\mathbf{2 3 \%}$ & 3 & $\mathbf{1 7 \%}$ & 6 \\
Investor wins on the merits & $23 \%$ & 3 & $17 \%$ & 6 \\
Investor loses on jurisdiction & $23 \%$ & 3 & $31 \%$ & 11 \\
Case settled & $31 \%$ & 4 & $9 \%$ & 3 \\
Case discontinued & $0 \%$ & 0 & $26 \%$ & 9 \\
\hline Total & $100 \%$ & 13 & $100 \%$ & 35 \\
\hline
\end{tabular}

If we take all of the non-BIT cases, we find that the overall win-loss percentages for claimantinvestors is a mere 14\%; and claimant-investors have not won a single case arising out of CAFTA-DR ${ }^{48}$ or any bilateral free trade agreements (BFTAs). Both the CAFTA-DR and all of the BFTAs involving environment-related disputes to date are considered new generation IIAs and are largely based on modifications that came with the model United States (US) BIT released in 2004. This is because the US is a contracting party to all these agreements and all of the disputes arising out of these agreements were brought by US claimant-investors. Interestingly, the majority of these disputes were dismissed at the jurisdictional stage and so the arbitral tribunal was never tasked with whether the environment-related measure violated the agreement. Only in one case did the arbitral tribunal dismiss the claimant-investors claim on the merits and in that case, the arbitral tribunal explicitly held that the environment-related measure did not violate the agreement. ${ }^{49}$

\subsection{Nature of the Treaty Provision}

Given that these newer generation of treaties like CAFTA-DR and US BFTAs provide many environment-related provisions, and claimant-investors have won none of these cases, one could easily speculate that it is these new rules requiring arbitrators to be more deferential to a state's environment-related measures that is driving these statistics. ${ }^{50}$ However, looking more

\footnotetext{
${ }^{48}$ Dominican Republic-Central American Free Trade Agreement.

${ }^{49}$ Adel A Hamadi Al Tamimi v Oman, ICSID Case No ARB/11/33, Award (3 November 2015).

${ }^{50}$ In recent scholarship and reports, there is empirical evidence supporting a rise in the types of environmentrelated provisions that might require investment treaty arbitrators to act more deferentially to respondent states in environment-related cases. See Kathryn Gordon and Joachim Pohl, 'Environmental Concerns in International Investment Agreements: a survey’ OECD Working Papers on International Investment No 2011/1 (2011); Amelia Keene, 'The incorporation and interpretation of WTO-style environmental exceptions in international investment agreements' Journal of World Investment and Trade (2016). However, none of the pending cases arising under these newer generation of IIAs have yet to be concluded. There are however a number of pending
} 
closely, it appears that claimant-investors have lost on jurisdiction in about $80 \%$ of these cases. Thus, it is difficult to argue that the stronger environmental provisions in these treaties might be responsible for increased claimant-investor losses. One might therefore conclude that one way to safeguard domestic environment-related measures is just to tighten the jurisdictional requirements under newer generation IIAs.

Figure 9: Treaty violation found in environment-related cases (20 cases)

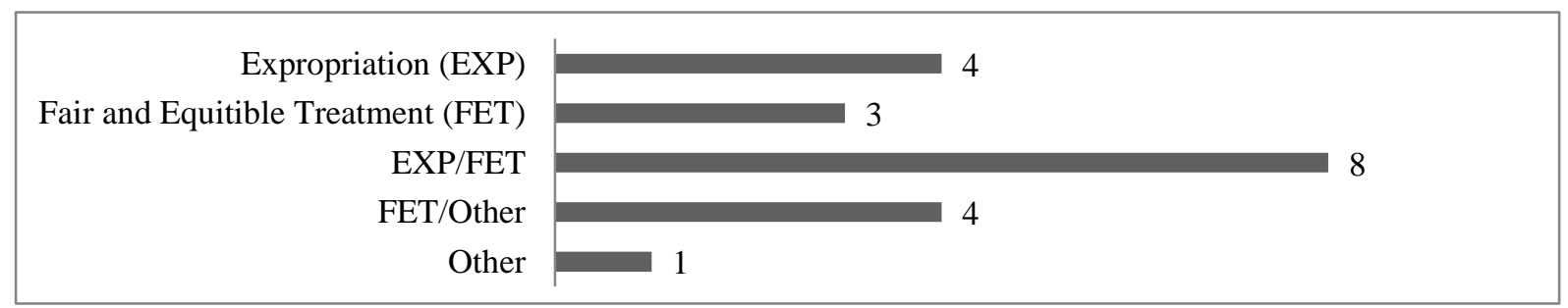

As to the breaches of the applicable IIA found in the 20 cases (in one case, the treaty violation found is unknown) where the claimant-investor won on the merits, there is considerable diversity with many of the cases finding multiple violations of the applicable IIA. 4 of the cases involved direct expropriations where the respondent state's justification for the cancellation of the concession or contract was based in whole or part on the claimantinvestor's failure to comply with environment-related processes. ${ }^{51} 7$ of the cases involved findings of indirect expropriation and 15 of the cases found the respondent state in breach of the fair and equitable treatment (FET) standard. Only a handful of cases involved violations other than expropriation and/or the FET standard.

One of the more surprising findings in regard to treaty violations in these types of cases is the high incidence of indirect expropriation and the high incidence of a finding that both the expropriation standard and the FET standard were violated. There is some evidence that the incidence of a finding of indirect expropriation is declining over time ${ }^{52}$ and that it is being replaced by an increased incidence of FET violations. The shift is likely due to the fact that an FET violation is easier standard for a claimant-investor to prove. However, at least in environment-related cases, this does not appear to reflect the actual caseload. A violation of the expropriation standard was found in $60 \%$ of the cases and in $40 \%$ of the cases an violation of the expropriation standard was coupled with an FET violation as well (Figure 9 above).

\subsection{Economic Sector Involved}

Turning to the economic sector involved in environment-related cases, we find that the number of sectors involved is limited in environment-related cases. Over $50 \%$ of the cases arise out of either the water and waste management sector or the extractive industries sector;

environment-related cases under CAFTA-DR that are likely to turn on the respondent state's reliance on the environment-related provisions in that treaty. See eg Spence International Investments LLC and Others $v$ Costa Rica, ICSID Case No UNCT/13/2, pending.

${ }^{51}$ Direct expropriations will generally present significant challenges for environment-related justifications in investment treaty arbitration. While there is good argument that the level of compensation awarded could/should be proportionate to the purpose of the expropriation (eg lower levels of compensation in the case of an environmental conservation purpose), it is very difficult under any configuration of international law to claim that a direct expropriation requires no compensation to the claimant-investor whatsoever.

${ }^{52}$ Krzysztof Pelc, 'Does the International Investment Regime Induce Frivolous Litigation?' SSRN Working Paper (2016). 
the other $50 \%$ of the cases primarily arise out the production-petrochemical sector and the real estate development sector with a couple cases in the agriculture and electricity generation sectors (see Figure 6 below).

Figure 10: Environment-related cases by economic sector (49 cases)

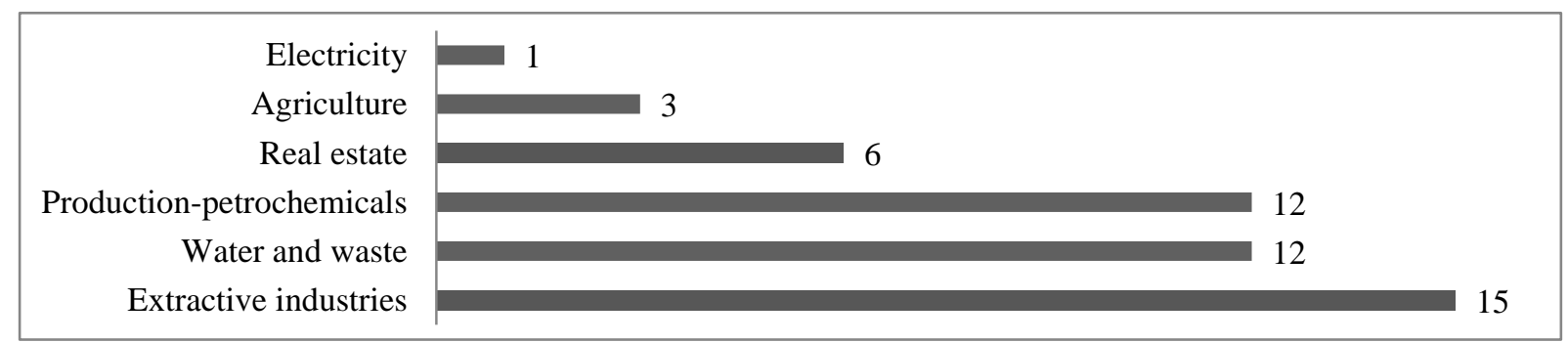

As highlighted in our analytic typology (Section 2), we have chosen to exclude cases where the subject-matter or economic sector relating to the dispute can said to be environmentrelated, but where there is no indication in the factual record that the foreign investor's claims included a challenge to a domestic environment-related measure or that the respondent state relied on any form of environment-related justification in defending itself against the claimant-investor's claims. For example, there are a large number of water and waste management sector cases where the dispute arose out of measures taken by the respondent state that did not relate to any domestic environmental justification. In Table 3 below, we provide the win-loss percentages for environment-related cases as well as a comparison between cases in particular economic sectors that have had both environment-related and nonenvironment-related cases (according to our analytic typology). The differences in outcomes is striking.

First, if we look at the win-loss percentages in environment-related cases in particular sectors we find that the economic sector matters. Almost all of the cases where the claimant-investor wins in an environment-related case come from either the extractive industries or the water and waste management sectors: 19 out of the 21 cases (90\%) where the claimant-investor won in an environment-related case come from these two economic sectors; and these two sectors also constitute the two most frequently involved economic sectors in environment-related cases (56\% of all cases). There may be structural features that can explain why these cases constitute such a large percentage of the cases in our dataset and why claimant-investors wins so frequently. Almost all of the environment-related cases in these two economic sectors involve a respondent state justifying the cancellation of a concession or contract on a domestic environment-related measure. For example, 69\% of the cases in these two economic sectors involve the cancellation of a concession or contract and of those cases the claimantinvestor won $89 \%$ of the time. In almost every one of these cases, the respondent state used an environment-related measure to justify the cancellation of the concession or concession, but the arbitral tribunal found that the environment-related measure was not justifiable as an excuse or exception to an IIA violation.

The next two most commonly involved economic sectors in environment-related cases are those involving production-petrochemicals and those involving real estate development. Most of these cases involve thwarted real estate development projects (like the Unglaube ${ }^{53}$ cases)

\footnotetext{
${ }^{53}$ Marion Unglaube v Costa Rica, ICSID Case No ARB/08/1, Award (16 May 2012); Reinhard Unglaube v Republic of Costa Rica, ICSID Case No ARB/09/20, Award (16 May 2012).
} 
or cases relating to the production of petrochemicals, steel or cement (like the Methanex ${ }^{54}$ or Chemtura $^{55}$ cases) where the respondent state justifies a ban (or a refusal to issue the required permits) on environmental protection reasons. In cases involving these 2 economic sector, the claimant-investor has not been successful, losing all but 2 cases. Combined, claimantinvestors have won in $11 \%$ of cases in these two economic sectors. For critics of investment treaty arbitration, these two economic sectors include most of cases that are frequently quoted as the most problematic for environmental protection (ie cases where the respondent state alleges that the measure taken that harms the foreign investor was required for environmental protection purposes). Overall, we find that by breaking down the environment-related cases into economic sectors, there is a very low rate of claimant-investor success in most of the prototypical cases that environmentalist allege are a challenge to environmental protection.

Table 3: Win-loss percentages by economic sector in environment-related cases

\begin{tabular}{|c|c|c|c|c|}
\hline \multirow[b]{2}{*}{ Outcome } & & \multicolumn{2}{|c|}{ All other cases } \\
\hline & \multicolumn{2}{|c|}{ Environment-related cases } & \multirow{2}{*}{ Percentage } & Cases \\
\hline $\begin{array}{l}\text { Extractive industries related } \\
\text { Investor wins on the merits }\end{array}$ & $67 \%$ & 10 & & 26 \\
\hline Investor loses on jurisdiction & $22 \%$ & 3 & $11 \%$ & 6 \\
\hline Investor loses on the merits & $14 \%$ & 2 & $14 \%$ & 8 \\
\hline Case settled & $0 \%$ & 0 & $26 \%$ & 15 \\
\hline Case discontinued & $0 \%$ & 0 & $3 \%$ & 2 \\
\hline Total & $100 \%$ & 15 & $100 \%$ & 57 \\
\hline $\begin{array}{l}\text { Water and waste management related } \\
\text { Investor wins on the merits }\end{array}$ & $75 \%$ & 9 & $40 \%$ & 8 \\
\hline Investor loses on jurisdiction & $9 \%$ & 1 & $15 \%$ & 3 \\
\hline Investor loses on the merits & $9 \%$ & 1 & $15 \%$ & 3 \\
\hline Case settled & $0 \%$ & 0 & $20 \%$ & 4 \\
\hline Case discontinued & $8 \%$ & 1 & $10 \%$ & 2 \\
\hline Total & $100 \%$ & 12 & $100 \%$ & 20 \\
\hline $\begin{array}{l}\text { Production-petrochemical related } \\
\text { Investor wins on the merits }\end{array}$ & $8 \%$ & 1 & $33 \%$ & 21 \\
\hline Investor loses on jurisdiction & $17 \%$ & 2 & $13 \%$ & 8 \\
\hline Investor loses on the merits & $33 \%$ & 4 & $29 \%$ & 18 \\
\hline Case settled & $42 \%$ & 5 & $14 \%$ & 9 \\
\hline Case discontinued & $0 \%$ & 0 & $11 \%$ & 7 \\
\hline Total & $100 \%$ & 12 & $100 \%$ & 63 \\
\hline $\begin{array}{l}\text { Real estate development related } \\
\text { Investor wins on the merits }\end{array}$ & $16 \%$ & 1 & $36 \%$ & 14 \\
\hline Investor loses on jurisdiction & $33 \%$ & 2 & $16 \%$ & 6 \\
\hline Investor loses on the merits & $33 \%$ & 2 & $23 \%$ & 9 \\
\hline Case settled & $17 \%$ & 1 & $15 \%$ & 6 \\
\hline Case discontinued & $0 \%$ & 0 & $10 \%$ & 4 \\
\hline Total & $100 \%$ & 6 & $100 \%$ & 39 \\
\hline Agriculture related & & & & \\
\hline Investor wins on the merits & $0 \%$ & 0 & $24 \%$ & 8 \\
\hline Investor loses on jurisdiction & $66 \%$ & 2 & $27 \%$ & 9 \\
\hline Investor loses on the merits & $0 \%$ & 0 & $12 \%$ & 4 \\
\hline Case settled & $34 \%$ & 1 & $15 \%$ & 5 \\
\hline Case discontinued & $0 \%$ & 0 & $22 \%$ & 7 \\
\hline Total & $100 \%$ & 3 & $100 \%$ & 33 \\
\hline Electricity generation related & & & & \\
\hline
\end{tabular}

\footnotetext{
${ }^{54}$ Methanex Corp v US, UNCITRAL, Award (3 August 2005).

${ }^{55}$ Chemtura Corp (formerly Crompton Corp) v Canada, UNCITRAL, Award (2 August 2010).
} 
Investor wins on the merits

Investor loses on jurisdiction

Investor loses on the merits

Case settled

Case discontinued

Total

\begin{tabular}{|c|c|c|c|}
$\mathbf{0 \%}$ & 0 & $27 \%$ & 18 \\
$0 \%$ & 0 & $14 \%$ & 9 \\
$0 \%$ & 0 & $18 \%$ & 12 \\
$100 \%$ & 1 & $41 \%$ & 27 \\
$0 \%$ & 0 & $0 \%$ & 0 \\
\hline $100 \%$ & 1 & $100 \%$ & 66 \\
\hline
\end{tabular}

Second, we turn to an assessment of environment-related cases in relation to all other investment treaty arbitrations involving the same economic sector. The most interesting finding is that in the extractive industries and water and waste management economic sectors, claimant-investors win significantly more often when the respondent state justifies its actions on environment-related grounds (see right columns in Table 3 below). The opposite is true for production-petrochemical and real estate development sector cases. In those cases, the claimant-investor wins significantly less often in environment-related cases than in all other cases involving the same economic sector. The other interesting finding here is that in all economic sectors - except the water and waste management sector - the environment-related cases only constitute a small percentage of the overall caseload. In the water and waste management sector, over one-third of all cases that have been brought include some kind of challenge to a domestic environment-related measure. The other economic sectors range between $1 \%$ and $26 \%$ in terms of the percentage of environment-related cases as compared with the overall caseload for each respective economic sector.

For purposes of completeness and before turning to the characteristics of respondent states in environment-related cases, we will look briefly at a sub-category of cases that are often included as environment-related: renewable energy cases. As stated in Section 2, we have excluded these cases from our primary dataset because the claimant-investors are not challenging a domestic environment-related measure in these cases. In fact, it can be argued that the measures taken by the host state in these cases could have detrimental impact on the environment. These renewable energy-related cases, along with the limited number of cases where the alleged violation of the relevant IIA is a host state's failure to protect the environment, can be categorized as an inverse type of environment-related case. Sullivan and Kirsey, for example, call these cases 'the use of environmental policies as a sword' in investment treaty arbitration. ${ }^{56}$ One could juxtapose this type against the type of cases that we include in our primary dataset where 'environmental policies ... [are] used as a shield [by respondent states in] legitimizing state measures that have affected foreign investment.'

Table 4: Overall win-loss percentages for renewable energy-related cases

\begin{tabular}{|c|c|c|c|c|}
\hline \multirow[b]{2}{*}{ Outcome } & \multicolumn{2}{|c|}{ Renewable energy-related } & \multicolumn{2}{|c|}{ All other electricity cases } \\
\hline & Percentage & Cases & Percentage & Cases \\
\hline Investor wins on the merits & $17 \%$ & 2 & $30 \%$ & 16 \\
\hline Investor loses on jurisdiction & $8 \%$ & 1 & $15 \%$ & 8 \\
\hline Investor loses on the merits & $42 \%$ & 5 & $13 \%$ & 7 \\
\hline Case settled & $33 \%$ & 4 & $42 \%$ & 23 \\
\hline Case discontinued & $0 \%$ & 0 & $0 \%$ & 0 \\
\hline Total & $100 \%$ & 12 & $100 \%$ & 54 \\
\hline
\end{tabular}

Looking specifically at renewable energy-related cases, however, we find that currently there

\footnotetext{
${ }^{56}$ Jeffrey Sullivan and Valeriya Kirsey, Environmental Policies: A Shield or a Sword in Investment Arbitration? Journal of World Investment and Trade (2016).
} 
are 12 fully resolved cases that fit this category: 6 cases involving hydro-energy generation, 2 cases involving wind energy generation, 2 cases involving geo-thermal power generation, and 2 cases involving photo-voltaic (PV) solar energy production (almost all of the more than 50 PV solar and CSP disputes against European Union (EU) Member States remain pending).

In Table 4 above, we provide the win-loss percentages for cases involving renewable energy production that have been concluded through 1 August 2016. The sample is very small but it is notable that when compared with all concluded cases in the PITAD dataset (Table 1 above) of all concluded cases is that: (1) renewable energy-related cases settle at a higher rate than cases in the complete dataset; and (2) claimant-investors in these types of cases have a significantly lower chance of success when the case goes through to the merits. This might be suggestive of a lack of responsiveness to environment-related concerns but we will need to wait for further decisions. However, it is noticeable that when we compare renewable energyrelated cases with all electricity generation cases in our complete PITAD dataset, we find that: (1) renewable energy-related cases are much less likely to find in favor of the claimantinvestor than in all other electricity generation cases; and (2) all types of electricity generation cases (including the renewable energy-related cases) have a much higher instance of settlement $(41 \%)$ than in all investment treaty arbitrations (22\%) and environment-related cases (14\%) (Table 1 above).

\subsection{Respondent State Characteristics}

One of the main charges against the practice of investment treaty arbitration is that there is an anti-developing state bias. Thus, we can ask if there is any indication that particular types of states are more of less likely to successfully defend themselves against a claimant-investor in an environment-related case. What is immediately apparent when looking at all environmentrelated cases in the dataset (49) is that the vast majority of all cases are brought against respondent states with more developed economies. Over $86 \%$ of all environment-related cases are against states falling within the two upper categories of the World Bank incomes groups ${ }^{57}$ (Table 5 below). Further, 55\% of the cases are exclusively against states in the upper income category. These are all states that are considered developed economies and most of them are $\mathrm{OECD}^{58}$ members. Only 7 of the environment-related cases are against respondent states in the lower middle and lower income groups.

Table 5: Win-loss percentages by World Bank income groups (49 cases)

\begin{tabular}{l|c|c|c|c|} 
Environment-related cases & Upper & Upper middle & Lower middle & Lower \\
\hline Investor wins on the merits & $42 \%$ & $60 \%$ & $17 \%$ & $0 \%$ \\
Investor loses on jurisdiction & $11 \%$ & $33 \%$ & $50 \%$ & $0 \%$ \\
Investor loses on the merits & $27 \%$ & $1 \%$ & $17 \%$ & $0 \%$ \\
Case settled & $19 \%$ & 0 & $16 \%$ & $100 \%$ \\
Case discontinued & $1 \%$ & 0 & $0 \%$ & $0 \%$ \\
\hline Total (number of cases) & $\mathbf{2 7}$ & $\mathbf{1 5}$ & $\mathbf{5}$ & $\mathbf{1}$ \\
\hline
\end{tabular}

Likewise, if we look at the respondent state's regulatory quality score as measured by the

\footnotetext{
${ }^{57}$ A respondent state's World Bank income group categorization is set for the year that the investment treaty arbitration was registered. See World Bank Country and Lending Groups <https://datahelpdesk.worldbank.org/ knowledgebase/articles/906519-world-bank-country-and-lending-groups> accessed 1 August 2016.

${ }^{58}$ Organization for Economic Cooperation and Development.
} 
World Bank's Worldwide Governance Indicators (WGI), ${ }^{59}$ a similar pattern emerges. The WGI regulatory quality score is an aggregate measure of a number of different indicators aimed at 'captur[ing] perceptions of the ability of the government to formulate and implement sound policies and regulations that permit and promote private sector development. ${ }^{60}$ The scores are calculated annually and range from a low score of $(-2)$ to a high score of (2). ${ }^{61} \mathrm{We}$ would hypothesize that states with higher levels of regulatory quality are more likely to have policies that promote private sector development, but that also are more likely to have strong regulatory regimes concerning environmental protection (and that would also be more likely to come into conflict with foreign investor property rights). What we find in our dataset confirms this hypothesis. $71 \%$ of all respondent states in environment-related cases in the dataset score between (0) and (2) (see Table 6 below). In other words, a majority of all respondent states in environment-related cases score relatively well in terms of the regulatory quality.

Table 6: Win-loss percentages by WGI regulatory quality scores (49 cases)

\begin{tabular}{l|c|c|c|c|} 
Environment-related cases & $>\mathbf{1}$ & $\mathbf{0}$ to $\mathbf{1}$ & $\mathbf{0}$ to -1 & \multicolumn{2}{c|}{-1 } \\
\hline Investor wins on the merits & $25 \%$ & $42 \%$ & $24 \%$ & $0 \%$ \\
Investor loses on jurisdiction & $18 \%$ & $32 \%$ & $13 \%$ & $0 \%$ \\
Investor loses on the merits & $37 \%$ & $21 \%$ & $25 \%$ & $0 \%$ \\
Case settled & $25 \%$ & $0 \%$ & $0 \%$ & $0 \%$ \\
Case discontinued & $0 \%$ & $1 \%$ & $\mathbf{8}$ & $\mathbf{6}$ \\
\hline Total (number of cases) & $\mathbf{1 6}$ & $\mathbf{1 9}$ & & \\
\hline
\end{tabular}

Finally, if we look at the geographic distribution of the environment-related cases, the pattern clusters around cases from North America and Latin America. $72 \%$ of all cases come from these two regions (Table 7 below).

Table 7: Win-loss percentages by geographic region (49 cases)

\begin{tabular}{l|c|c|c|c|c|c|c|} 
Environment-related cases & NA & LA & EE & WE & SEA & SSA & ME \\
\hline Investor wins on the merits & $18 \%$ & $58 \%$ & $38 \%$ & $50 \%$ & $50 \%$ & $0 \%$ & $0 \%$ \\
Investor loses on jurisdiction & $18 \%$ & $34 \%$ & $0 \%$ & $0 \%$ & $50 \%$ & $0 \%$ & $0 \%$ \\
Investor loses on the merits & $37 \%$ & $4 \%$ & $50 \%$ & $0 \%$ & $0 \%$ & $0 \%$ & $100 \%$ \\
Case settled & $37 \%$ & $4 \%$ & $12 \%$ & $50 \%$ & $0 \%$ & $100 \%$ & $0 \%$ \\
Case discontinued & $0 \%$ & $0 \%$ & $0 \%$ & $0 \%$ & $0 \%$ & $0 \%$ & $0 \%$ \\
\hline Total (number of cases) & $\mathbf{1 1}$ & $\mathbf{2 4}$ & $\mathbf{8}$ & $\mathbf{2}$ & $\mathbf{2}$ & $\mathbf{1}$ & $\mathbf{1}$ \\
\hline
\end{tabular}

Using these three indicators, a striking pattern emerges. Environment-related cases tend to arise predominantly in respondent states whose characteristics are in direct opposition to the mainstream perception that investment treaty arbitration targets poor states in developing regions of the world that have relatively low levels of governance. What we find in the aggregate with environment-related cases is that they arise in developed economies with relatively high levels of regulatory quality. While this may be intuitively surprising, it has a likely explanation. Cases that challenge domestic environment-related measures occur more frequently in developed economies with sophisticated regulatory governance regimes because

\footnotetext{
${ }^{59}$ Worldwide Governance Indicators < http://info.worldbank.org/governance/wgi/index.aspx\#home > accessed 1 August 2016.

${ }^{60}$ Ibid.

${ }^{61}$ The WGI regulatory quality score for each respondent state is given according to the year that the relevant investment treaty arbitration was registered.
} 
it is these types of states that are more likely to have advanced and entrenched systems for the regulation of the environment. Further, it is less likely that these states will be willing to modify or alter generally applicable regulations for the protection of the environment in order to appease an aggrieved foreign investor. The result is that foreign investors are most likely to have disputes that arise in developed economies than in lesser developed states.

While the development status, regulatory quality, and geographic region do seem to matter in whether a respondent state will attract cases based on challenges to a domestic environmentrelated measure, the picture is less clear when looking at outcomes in cases as based on these three state characteristic criteria. Tables 5 and 6 above show the outcomes for environmentrelated cases as broken down by state characteristics. There are a couple patterns worth noting, although with the caveat that many of the categories have too few cases to draw any strong conclusions. For development status, as measured by World Bank income groups, claimant-investors appear to do better in more developed states. This is the opposite of the overall win-loss percentages for all investment treaty arbitrations. In a recent article, we show that the lower a state's gross domestic product (GDP) per capita, the more likely that state will lose in an investment treaty arbitration. ${ }^{62}$ Looking at the overall percentages by income groups (which is measured by gross national income (GNI) per capita, not GDP) in environment-related cases, poorer states do better than wealthier states.

Looking at the regulatory quality scores in relation to outcomes in environment-related cases, the pattern is expected. The higher the regulatory quality score, the more likely the respondent state will successfully defend itself in an investment treaty arbitration. For respondent states with the highest regulatory quality scores (ie above a score of (1)), claimant-investors only succeed in $25 \%$ of the cases. If you look at cases where the respondent state scores above a (1.5), the win rate for claimant-investors drops even further to $16 \%$. One might expect that there be significant correlation between development status and regulatory quality, but in terms of outcomes, a state with a high regulatory quality score has a much high chance of successfully defending itself in an environment-related case than a state with a high development status (see the difference in the far left columns in Tables 5 and 6 above). For geographic region, it is most striking to note that in cases against North American states (US, Canada, Mexico), claimant-investors have a very low success rate overall (18\%). It is wellknown that in all investment treaty arbitrations to date against the US, the US has not lost a single case. US success is thus pulling down the win-loss percentages for the cases against Mexico and Canada. In terms of environment-related cases, claimant-investors in cases against Canada and Mexico have win rates of 50\%.

\subsection{Arbitrators and Legal Counsel}

In this sub-section, we will assess the possible relationship between environment-related cases and the arbitrators sitting on these cases and the counsel representing the parties. While we see a large number of prominent arbitrators sitting in these cases and a high percentage of high quality legal counsel representing both claimant-investors and respondent states in these cases, there do not appear to be any readily identifiable patterns in relation to outcomes. We define a prominent arbitrator as an individual that has rendered decisions in five or more investment treaty arbitrations as a tribunal president through 1 August 2016. We define high quality counsel, while imprecise, as the frequency with which a claimant-investor or

\footnotetext{
${ }^{62}$ Behn, Berge, and Langford (n 33).
} 
respondent state retains counsel from a Global 100 law firm. ${ }^{63}$

Figure 8: Arbitrators and legal counsel in environment-related cases
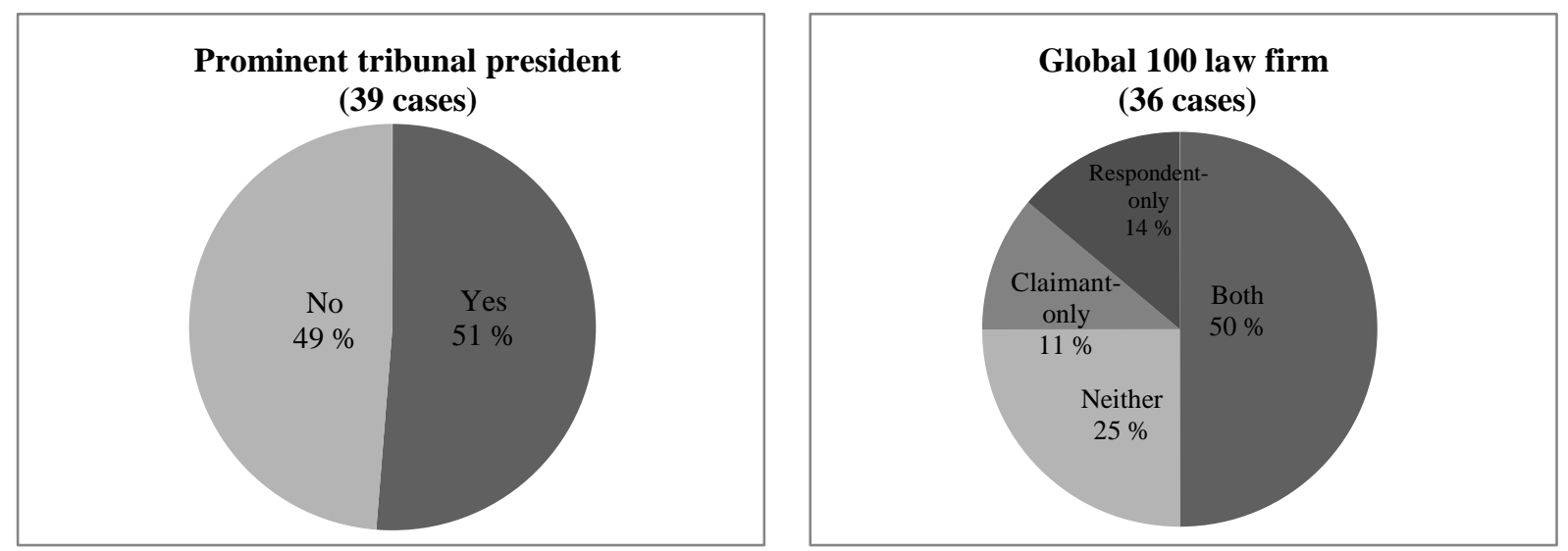

For both quality counsel and prominent arbitrators, we find that the outcomes in these cases does deviate significantly from the overall win-loss percentages in all environment-related cases. In cases with prominent tribunal presidents, claimant-investors have won $50 \%$ of the time (10 out of 20 cases). In other words, there does not appear to be a significant effect that is derived from cases with either prominent arbitrators or quality counsel. For example, the most frequent prominent arbitrator to sit as a president in environment-related cases is Gabrielle Kaufmann-Kohler (4 cases). In the cases where she is president, the claimantinvestor has won 2 cases and lost 2 cases. For counsel, we would expect cases where one side has retained a Global 100 law firm, and the other side has not, to have an affect on outcome. However, there is none. In cases where only claimant-investors have retained Global 100 counsel, they have won $50 \%$ of the time ( 2 out of 4 cases). In cases where only the respondent state has retained Global 100 counsel, claimant-investors have won $40 \%$ of the time (2 out of 5 cases). Overall, we would expect there to be an emerging competence among both arbitrators and legal counsel in environment-related cases, but to date we do not identify any clear patterns (at least in regards to outcomes). Of course, this does not mean that the quality of counsel or the selection of arbitrators does not matter in investment treaty arbitration generally or environment-related cases specifically: it does. It is just that in this small sub-set of investment treaty arbitrations (49 cases), no clear patterns are apparent yet.

\subsection{Regression Analysis}

In this section we analyze which of these structural factors correlates best with the outcomes. In other words, does the presence of a structural, legal, procedural or time factor increase the chances that an investor will win in an environment-related case? Table 8 below shows the results for a multivariate logit regression analysis on the outcomes using Any Win as the dependent variable. The first column shows the results with a set of controls which we have used previously in analyzing investment arbitration outcomes, the second column shows the factors without controls and the final column shows the factors with controls.

Table 8: Multivariate logit regression analysis of environment-related case factors

${ }^{63}$ American Lawyer (n 30). 


\section{Conclusion}

\section{Annex I: List of Environment-Related Investment Treaty Arbitrations}

\begin{tabular}{|c|c|c|c|c|c|}
\hline No & Case & Treaty & Fora & Outcome & Year \\
\hline 1 & Saar Papier v Poland (Saar I) & BIT & UNCITRAL & Claimant wins on the merits & 1995 \\
\hline 2 & Ethyl Corp v Canada & NAFTA & UNCITRAL & Case settled & 1999 \\
\hline 3 & Maffezini v Spain & BIT & ICSID & Claimant wins on the merits & 2000 \\
\hline 4 & Metalclad v Mexico & NAFTA & ICSID & Claimant wins on the merits & 2000 \\
\hline 5 & Saar Papier v Poland (Saar II) & BIT & UNCITRAL & Claimant loses on the merits & 2000 \\
\hline 6 & SD Myers v Canada & NAFTA & UNCITRAL & Claimant wins on the merits & 2000 \\
\hline 7 & Vivendi v Argentina (A) & BIT & ICSID & Claimant wins on the merits & 2000 \\
\hline 8 & Schaper v Poland (Saar III) & BIT & UNCITRAL & Claimant wins on the merits & 2001 \\
\hline 9 & Tecmed v Mexico & BIT & ICSID & Claimant wins on the merits & 2003 \\
\hline 10 & MTD Equity v Chile & BIT & ICSID & Claimant wins on the merits & 2004 \\
\hline 11 & Lucchetti v Peru & BIT & ICSID & Claimant loses on jurisdiction & 2005 \\
\hline 12 & Methanex v US & NAFTA & UNCITRAL & Claimant loses on the merits & 2005 \\
\hline 13 & Bayview v Mexico & NAFTA & ICSID AF & Claimant loses on jurisdiction & 2007 \\
\hline 14 & Eduardo Vieira v Chile & BIT & ICSID & Claimant loses on jurisdiction & 2007 \\
\hline 15 & Parkerings v Lithuania & BIT & ICSID & Claimant loses on the merits & 2007 \\
\hline 16 & Shell Brands v Nicaragua & BIT & ICSID & Case settled & 2007 \\
\hline 17 & Vivendi v Argentina (B) & BIT & ICSID & Claimant wins on the merits & 2007 \\
\hline 18 & Canadian Cattlemen v US & NAFTA & UNCITRAL & Claimant loses on jurisdiction & 2008 \\
\hline 19 & Plama v Bulgaria & ECT & ICSID & Claimant loses on the merits & 2008 \\
\hline 20 & Glamis Gold v US & NAFTA & UNCITRAL & Claimant loses on the merits & 2009 \\
\hline 21 & Chemtura v Canada & NAFTA & UNCITRAL & Claimant loses on the merits & 2010 \\
\hline 22 & Chevron v Ecuador (I) & BIT & PCA & Claimant wins on the merits & 2010 \\
\hline 23 & Vattenfall v Germany (I) & ECT & ICSID & Case settled & 2010 \\
\hline 24 & Commerce Group v El Salvador & CAFTA & ICSID & Claimant loses on jurisdiction & 2011 \\
\hline 25 & Dow AgroSciences v Canada & NAFTA & UNCITRAL & Case settled & 2011 \\
\hline 26 & Gallo v Canada & NAFTA & PCA & Claimant loses on jurisdiction & 2011 \\
\hline 27 & Greiner v Canada & NAFTA & UNCITRAL & Case settled & 2011 \\
\hline 28 & Paushok v Mongolia & BIT & UNCITRAL & Claimant wins on the merits & 2011 \\
\hline 29 & Accession v Bulgaria & BIT & ICSID & Case discontinued & 2012 \\
\hline 30 & Burlington v Ecuador & BIT & ICISD & Claimant wins on the merits & 2012 \\
\hline 31 & Pac Rim v El Salvador & CAFTA & ICSID & Claimant loses on jurisdiction & 2012 \\
\hline 32 & Unglaube v Costa Rica (I) & BIT & ICSID & Claimant wins on the merits & 2012 \\
\hline 33 & Unglaube v Costa Rica (II) & BIT & ICSID & Claimant loses on the merits & 2012 \\
\hline 34 & Abengoa v Mexico & BIT & ICSID AF & Claimant wins on the merits & 2013 \\
\hline 35 & Bogdanov v Moldova (IV) & BIT & SCC & Claimant loses on the merits & 2013 \\
\hline 36 & McKenzie v Vietnam & BFTA & UNCITRAL & Claimant loses on the merits & 2013 \\
\hline 37 & St. Mary’s v Canada & NAFTA & PCA & Case settled & 2013 \\
\hline 38 & Gold Reserve v Venezuela & BIT & ICSID & Claimant wins on the merits & 2014 \\
\hline 39 & Perenco v Ecuador & BIT & ICSID & Claimant wins on the merits & 2014 \\
\hline 40 & Al Tamimi v Oman & BFTA & ICSID & Claimant loses on the merits & 2015 \\
\hline 41 & Bilcon v Canada & NAFTA & PCA & Claimant wins on the merits & 2015 \\
\hline 42 & Novera v Bulgaria & BIT & ICSID & Claimant wins on the merits & 2015 \\
\hline
\end{tabular}




\begin{tabular}{l|l|l|l|l|l|}
\hline 43 & Quiborax v Bolivia & BIT & ICSID & Claimant wins on the merits & 2015 \\
\hline 44 & Renée Levy v Peru & BFTA & ICSID & Claimant loses on jurisdiction & 2015 \\
\hline 45 & Copper Mesa v Ecuador & BIT & PCA & Claimant wins on the merits & 2016 \\
\hline 46 & Corona v Dominican Republic & CAFTA & PCA & Claimant loses on jurisdiction & 2016 \\
\hline 47 & Crystallex v Venezuela & BIT & ICSID & Claimant wins on the merits & 2016 \\
\hline 48 & Renco v Peru & BFTA & UNCITRAL & Claimant loses on jurisdiction & 2016 \\
\hline 49 & VICAT v Senegal & BIT & UNCITRAL & Case settled & 2016 \\
\cline { 2 - 6 }
\end{tabular}

